\title{
Contribution to the knowledge of the non-calcareous grasslands of the Monti Sibillini National Park (central Italy): coenological structure, syntaxonomy, ecology, and floristic aspects
}

\author{
Sandro Ballelli ${ }^{1}$, Federico Maria Tardella ${ }^{1}$ (i) Riccardo Pennesi $^{1}{ }^{(1)}$, \\ Tiziana Panichella ${ }^{2}$ (D) Alessandro Bricca ${ }^{3}$ (D) , Alessandra Vitanzi ${ }^{3}$ \& \\ Andrea Catorci ${ }^{3}$
}

Key words: arenaceous substrates, flora of conservation interest, grasslands, plant sociology.

Ključne besede: peščenjak, zavarovana flora, travišča, fitosociologija.
Corresponding author:

Tiziana Panichella

E-mail: tiziana.panichella@unicam.it

Received: 9. 7. 2021

Accepted: 13. 10. 2021

\begin{abstract}
This study provides the first contribution to the knowledge of the non-calcareous grasslands of the arenaceous sector of the Monti Sibillini National Park (central Italy). We conducted 55 relevés using the Braun-Blanquet phytosociological method and analysed the ecology of plant communities by Redundancy analysis using topographic variables and Ellenberg Indicator Values as predictors. We identified nine plant communities, belonging to four classes. Communities of CallunoUlicetea and Nardetea strictae were found on acidic soils at higher elevations, those of Festuco-Brometea were mainly associated with steeper south-facing slopes, while Molinio-Arrhenatheretea communities were associated with low altitudes and gentle slopes, semi-flat lands, and high soil nutrient and moisture values. We recorded a total of 410 taxa at the species and subspecies level, representing about $20 \%$ of the flora of the Monti Sibillini National Park. Some of these are of high conservation interest, e.g. Calluna vulgaris, Genista sagittalis, Juncus capitatus, and Ophioglossum vulgatum. Eight species are new to the flora of Sibillini National Park.
\end{abstract}

Izvleček

Članek predstavlja prve prispevke $\mathrm{k}$ poznavanju travišč na nekarbonatni podlagi na peščenjaku v Narodnem parku Monti Sibillini (srednja Italija). Naredili smo 55 popisov z Braun-Blanquetovo metodo in analizirali ekologijo rastlinskih združb $\mathrm{z}$ analizo renundance (RDA) z uporabo topografskih spremenljivk in Ellenbergovih indikatorskih vrednosti kot neodvisnih spremenljivk. Identificirali smo devet rastlinskih združb, ki jih uvrščamo v štiri razrede. Združbe iz razredov Calluno-Ulicetea in Nardetea strictae smo našli na kislih tleh na višjih nadmorskih višinah, tiste iz razreda Festuco-Brometea pa na strmih južnih pobočjih, medtem ko se združbe iz razreda Molinio-Arrhenatheretea pojavljajo v nižinah na blagih naklonih, bolj ali manj ravnih površinah, na tleh z večjo vsebnostjo hranil in vlažnostjo. Zabeležili smo 410 taksonov (vrst in podvrst), ki predstavljajo 20\% flore Narodnega parka Monti Sibillini. Nekateri so pomembni z vidika ohranjanja, kot npr. Calluna vulgaris, Genista sagittalis, Juncus capitatus in Ophioglossum vulgatum. Osem vrst je v flori Narodnega parka Monti Sibillini zabeleženih prvič.

\footnotetext{
1 Herbarium Universitatis Camerinensis, School of Biosciences and Veterinary Medicine, Camerino (MC), Italy.

2 School of Advanced Studies, Camerino (MC), Italy.

3 School of Biosciences and Veterinary Medicine, Camerino (MC), Italy.
} 


\section{Introduction}

In the Apennine mountains (central Italy), semi-natural grasslands extend over vast areas representing an important cultural heritage (Antrop, 2004), and a biotope of high conservation interest (Sebastià et al., 2008). Most of these communities are protected habitat types included in the 92/43/EEC Directive and play a key role in the conservation of Italian endangered fauna and flora. These communities are threatened by land abandonment, management changes and rapid dynamic processes (Mazzoleni et al., 2004; Falcucci et al., 2007). Therefore, the conservation of this valuable natural heritage is of great importance (Bricca et al., 2020). For this purpose, knowledge of floristic composition, distribution, dynamics, and biodiversity is a fundamental first step (Gigante et al., 2016). However, not all the ecological and geographical features of the Apennine grasslands are yet well known and described, especially the semi-natural, non-calcareous grasslands, which are likely to represent an important biodiversity hotspot, as most of the Apennine chains are mainly composed of limestones.

The "Monti Sibillini" National Park is the northernmost National Park of central Italy and hosts more than 2,000 vascular plant species on about 70,000 hectares (Ballelli et al., 2010). From a geological point of view, it could be divided into two main parts: the larger part is composed of limestone rocks (about the 90\% of the protected area) and a smaller part is formed by arenaceous and marly-arenaceous substrates, often covered by acid or sub-acid soils (less than 5\% of the protected area). Composition patterns of pastures and meadows besides their classification are poorly studied in the Park and no studies have been performed on arenaceous substrates. On calcareous substrates and lacustrine/marsh deposits a pioneer work by Cortini Pedrotti et al. (1973) addressed the pastures and meadows of Pian Grande di Castelluccio di Norcia, followed by studies on Pian Perduto di Gualdo (Pedrotti \& Cortini Pedrotti, 1982), Marcite di Norcia (Orsomando \& Pedrotti, 1982), Ragnolo (Francalancia et al., 1981; Catorci et al., 2007), steppe grasslands dominated by Stipa dasyvagynata subsp. apenninicola and Stipa capillata in the Norcia basin (Ballelli et al., 2006), pastures of the Ambro Valley (Catorci et al., 2008), and alpine and subalpine grasslands of the mountain tops (Costanzo et al., 2009).

Regarding arenaceous substrates of Monti della Laga (the nearest conspicuous arenaceous rock complex), Pedrotti (1982) collected relevés on some acidophilous plant communities (Vaccinio-Hypericetum richeri, BrachypodioFestucetum spadiceae, Poo violaceae-Nardetum, Carici-Elynetum bellardii). Di Pietro et al. (2001) described a new association of the Linario-Festucion dimorphae; Allegrezza et al. (2007) reported in Valle della Corte some associations never before indicated in the Monti della Laga. Di Pietro (2007) published a contribution on the beech forests. Finally, Allegrezza et al. (2013) published a paper on the vegetation of Piè Vettore, in the middle between the two geological systems, including new mountain grassland associations.

No complete floristic checklist has yet been published on the Monti Sibillini National Park. The most conspicuous contributions refer to Ballelli et al. (2005), who published the data of the Herbarium Vittorio Marchesoni, kept at the Herbarium Universitatis Camerinensis (CAME), including 1281 taxa at the species and subspecies level, and Ballelli et al. (2010), who collected references to 1920 taxa. Other floristic records referred to the flora of the Monti della Laga, but outside our study area are from Tondi (2000), Bartolucci et al. (2012), Ballelli \& Allegrezza (2016), and Conti \& Bartolucci (2016).

The aim of this study was to provide the first contribution to the knowledge of the non-calcareous grasslands of the arenaceous sector of the Monti Sibillini National Park.

Our specific research aims were: i) to assess the floristic relevance of these grasslands for the Monti Sibillini National Park; ii) to identify the herbaceous plant communities from a phytosociological point of view; iii) to describe the ecology of the different vegetation types using the Ellenberg Indicator Values (EIVs) and topographic data; iv) to identify the main environmental drivers of species composition.

\section{Materials and methods}

\section{Study area}

The study area is a hilly and low-montane area (500$1494 \mathrm{~m}$ a.s.1.) that extends at the foot of the south-eastern side of the Sibillini Mountains ridge (whose peaks generally exceed 2,000 $\mathrm{m}$ a.s.1.), in the central-western sector of the Province of Ascoli Piceno (Marche region, Italy). It is largely part ofthe Monti Sibillini National Park (Figure 1).

The bedrock consists of arenaceous substrates (Laga Formation) and arenaceous-pelithic deposits, with thick, poorly permeable, arenaceous banks forming the top of the hills (Centamore et al., 1991). The landforms consist of deep valleys, delimited by very steep slopes, and flat areas or not very steep slopes in the summit areas or adjacent to the limestone outcrops. Where sandstones outcrop, they give rise to very harsh landforms, while where the sandstones alternate with pelites, asymmetric landforms develop. In particular, where the arenaceous layers have opposite orientation to the slope inclination, slopes 


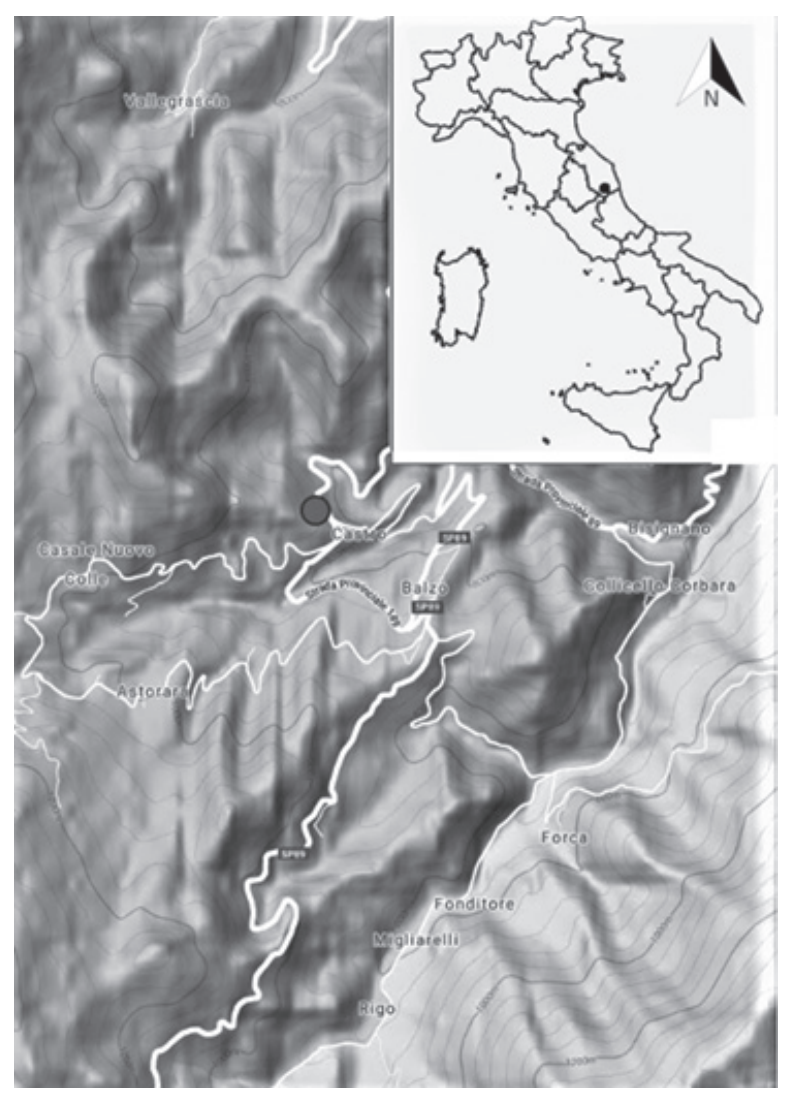

Figure1: Location of the study area (central Italy).

Slika 1: Preučevano območje (srednja Italija).

are very steep and sometimes interrupted by significant rocky cliffs. In contrast, slopes are quite gentle when the arenaceous layers are oriented in the same direction as the slope and are generally thicker (Centamore et al., 1991). Semi-flat areas correspond to basins covered by debris, often next to the geological division between calcareous and arenaceous outcrops. Soils are characterized by high desaturation, low active calcium content, $\mathrm{pH}$ less than 6 , sandy, sandy loam or sandy clay loam texture and moderate to medium depth (ASSAM, 2006).

The mean annual temperature is $11.1^{\circ} \mathrm{C}$, the mean annual precipitation is $1,217 \mathrm{~mm}$, the mean monthly temperature is below $10^{\circ} \mathrm{C}$ for 6 months, and the summer drought stress (Mitrakos, 1980) is absent (data from the Montemonaco thermo-pluviometric station, $987 \mathrm{~m}$ a.s.l., 1950-2000; Amici \& Spina, 2000). According to Pesaresi et al. (2017), the area belongs to the sub-Mediterranean bioclimatic variant of the temperate macro-bioclimate, with a weak Submediterraneity index, within the upper meso-temperate and lower supra-temperate bioclimatic belts, with lower and upper humid ombrotypes.

The vegetation mosaic of the study area is mostly characterized by forests dominated by Ostrya carpinifo- lia, Quercus pubescens and/or Quercus cerris below 900$1000 \mathrm{~m}$ a.s.l. and by Fagus sylvatica above this altitude (see Catorci et al., 2008). Forests generally cover the moderate to very steep slopes and the top of the hills. Pastures are generally distributed in the moderate to steep slopes, with the exception of the mowed meadows that characterize the semi-flat lands as well as croplands.

In the last decades, the area has been subject to an abandonment trend, which led to a very strong expansion of woodlands and a reduction of agricultural land and low productive pastures such as those the facing south (Brachetti et al., 2012).

\section{Data collection}

We conducted 55 phytosociological relevés (late May-July 2015) using the Braun-Blanquet phytosociological method (Braun-Blanquet, 1964), which implies a preferential sampling of vegetation units. We sampled grasslands (pastures and meadows) and a dwarf-shrub community occurring in patches inside pastures. The area of the plots ranged from $3 \mathrm{~m}^{2}$ (dwarf shrub community) to $200 \mathrm{~m}^{2}$ (dry grassland communities). For each relevé, we recorded the following data: locality (i.e., the locality closest to the plot, indicated on a topographic map), altitude (m a.s.l., measured using a digital GPS altimeter -1 -m resolution), slope aspect (azimuth degrees, measured using a compass - 1-degree resolution), slope angle (vertical degrees, measured using a clinometer - 1-degree resolution), total vegetation cover $(\%)$, and cover-abundance values of the species, the latter assigned using the Braun-Blanquet scale (Braun-Blanquet, 1964). The species nomenclature followed Bartolucci et al. (2018a, 2018b, 2018c, 2019a, 2019b).

We assigned to each species the Ellenberg Indicator Values (EIVs; Ellenberg et al., 1991) for light intensity (L), air temperature $(\mathrm{T})$, continentality $(\mathrm{C})$, soil moisture (M) and soil nutrients $(\mathrm{N})$, adapted to Italian flora (Pignatti et al., 2005; Guarino et al., 2012). The use of EIVs (Ellenberg, 1974; Ellenberg, 1996; Ellenberg et al., 1992) allows a better understanding of the relations between species composition and ecological factors and has proven useful in analysing the drivers of vegetation change across environmental and management gradients (e.g., Schaffers \& Sykora, 2000; Wamelink et al., 2002; Klaus et al., 2012), especially when they are used for comparisons on a local scale, within homogeneous bioclimatic and biogeographic contexts (Godefroid \& Dana, 2007).

To characterize the study area from a floristic perspective, we integrated the list of species recorded in the phytosociological survey with those found in the areas surrounding the plots. Moreover, the floristic records come from the V. Marchesoni Herbarium (Ballelli et al., 2005) 
and the S. Ballelli Herbarium (unpublished data) stored in the Herbarium Universitatis Camerinensis (CAME), as well as from the data sheet of the floristic area of the Marche region "99. Santa Maria in Pantano" (Regione Marche, 2014).

\section{Data analysis}

To characterize the floristic value of the studied grasslands, we calculated the chorological spectrum of the floristic list obtained following the chorological indications reported in Pignatti (2017a, 2017b, 2018, 2019). We grouped species into eight main components: Mediterranean, European, Eurasian, Boreal, Endemic, Atlantic, wide-distribution, and undefined distribution. Finally, we extracted from the list the taxa at the species and subspecies level that are considered rare in the Marche region, are included in Italian Red-list, are relevant from a biogeographical point of view (endemic, circumboreal or at the extreme border of their distribution range), or are new to the flora of the Monti Sibillini National Park.

We transformed Braun-Blanquet cover-abundance classes to percentages using the average cover values of Braun-Blanquet classes: + (< 1\%), $0.5 \%$; $1(1-5 \%), 3 \%$; 2 (5-25\%), 15\%; 3 (25-50\%), 37.5\%; 4 (50-75\%), $62.5 \%$; 5 (75-100\%), $87.5 \%$. To r values (rare species) we attributed $0.1 \%$.

To classify the plant communities, we performed cluster analysis on the Hellinger-transformed "relevé-byspecies cover (percentage)" matrix, using the complete link algorithm, based on Euclidean distance. To describe plant communities based on their coenological composition, we grouped species within each cluster following the most accepted phytosociological placement of each species at the class rank (Biondi \& Blasi, 2015; Mucina et al., 2016). Then, we grouped species of different classes based on their ecological affinity (e.g., we grouped species of Festuco-Brometea, Festuco-Ononidetea, etc.). For each plant community, we summed the average percent cover values of the Braun-Blanquet classes of species belonging to each phytosociological class or group of classes considered and calculated the percentage contribution of each species group to the total vegetation cover (sum of species cover values in all the relevés of each cluster).

For the syntaxonomic classification of the vegetation types, we referred to Biondi \& Blasi (2015) and Mucina et al. (2016). The nomenclature of suballiances, alliances and higher syntaxonomic ranks was drawn from Biondi et al. (2005), Biondi \& Blasi (2015), Mucina et al. (2016). For nomenclature at the association level, we mainly referred to Pedrotti (1976), Biondi \& Ballelli (1995), Allegrezza \& Biondi (2011), and Biondi \& Galdenzi (2012).
Moreover, we identified constant, dominant, and diagnostic species for each group. We considered as "constant" those species whose frequency within each group is higher than $40 \%$ (Poldini \& Sburlino, 2005) and as "dominant" those species (sensu Mucina et al., 1993) that occur in at least $60 \%$ of the relevès of a given group with a mean cover value higher than $25 \%$. To identify the diagnostic species of each plant community resulting from the cluster analysis, we performed an indicator species analysis (ISA; Dufrene \& Legendre, 1997). This method combines information on the abundance of species in a group and the occurrence of that species in a given group (McCune \& Grace, 2002). An indicator value $\left(\mathrm{IV}_{i j}\right)$ for species $i$ in group $j$. is obtained as the product of relative abundance (mean abundance of species $i$ within group $j$ divided by the sum of the mean abundance of species $i$ in all groups) and relative frequency (number of samples in group $j$ occupied by species $i$ divided by the total number of samples in group $j$ ), and ranges from 0 to 1 (Dufrêne $\&$ Legendre, 1997). We tested the statistical significance $(P<0.05)$ of the observed maximum IVs using permutation tests with 1,000 runs, and discarded species whose component of relative abundance was less than 0.6 or whose component of relative frequency was less than 0.25 (De Caceres et al., 2012).

To characterize the environmental conditions of the plant communities, we calculated descriptive statistics of EIVs and environmental characteristics for each main group highlighted by the cluster analysis. To calculate the EIVs at plot level we made the modification of the equation described by Garnier et al. (2004) and we multiplied the "relevé-by-species presence/absence" matrix by the "species x EIVs" matrix obtaining the "relevé-by-EIVs" matrix as follows:

$C M_{E I V}=\sum_{i=1}^{S} p_{i} x_{i}$

where CM is the community-unweighted mean value of a given EIV (i.e. the mean values of EIV at relevé level), $p_{i}$ is the relative cover of species $\mathrm{i}(\mathrm{i}=1,2, \ldots, S)$, and $x_{i}$ is the value of EIV for species $i$. In case of presence/absence species values, as for our case, $p_{i}=1 / N$ for all $N$ species in the sampling site. EIVs at the relevé level reflect the site conditions better than the EIVs at species level because the occurrence of a species in a relevé may deviate from its optimum due to ecological tolerance (Kowarik \& Seidling, 1989).

To investigate the effect of the topographic variables on species composition, we performed a redundancy analysis (RDA) by using as dependent variables the "relevé-byspecies cover (percentage)" matrix after Hellinger trans- 
formation and elevation, slope, and aspect as predictors. Prior to this analysis, aspect values were converted from the compass scale $0-360$ to a linear scale $(0-180)$, with northern aspect (the shadiest) receiving a value approaching 0 and southern aspect (the sunniest) receiving a value approaching 180 (Warren, 2008). The significance of the RDA model and each predictor was tested using permutation tests (999 iterations). Then, we used $\mathrm{CM}_{\mathrm{EIVs}}$ as "supplementary" variables to highlight the ecological gradients depicted by RDA axes 1 and 2 . Since dependent variables (i.e., species cover) and predictors (i.e., $\mathrm{CM}_{\mathrm{EIV}}$ ) are not independent, the results may inflate Type I error. To avoid such effect, we used the approach based on permutation model described by Zelený \& Schaffers (2012). We shuffled species identity 999 times in the EIVs matrix (i.e., we randomly assigned the EIVs across the species) and compared the observed coefficient of determination (obs. $\mathrm{R}^{2}$ ) of each of the linear regressions between each $\mathrm{CM}_{\mathrm{EIV}}$ and the ordination axes to a null distribution of 999 expected coefficients of determination (exp. $\mathrm{R}^{2}$ ). The linear regressions were not due to the chance and not affected by error Type I only if the obs. $\mathrm{R}^{2}$ was significantly higher than the exp. $\mathrm{R}^{2}$ based on a one-tailed t-test $(\alpha=0.05)$.

Statistical analyses were performed using $\mathrm{R}$ software version 3.5.3 (R Foundation for Statistical Computing, Vienna, Austria, http://www.R-project.org). To perform cluster analysis, we used the hclust function (stats package, version 3.0.2) and the vegdist function (vegan package, version 2.4-3). The ISA was performed using the multipatt function (indicspecies package, version 1.7.9). To perform the Hellinger transformation, we used the decostand function of vegan. RDA was performed using the $r d a$ function, scaling = 2 (vegan package). The significance of the first RDA model for each predictor and the $\mathrm{RDA}$ axes were tested using the anova.cca function (vegan package). To compare the observed and expected $R^{2}$ in the second RDA, we used the envifit.iv function provided by Zelený \& Schaffers (2012), which could be run in $\mathrm{R}$ version 3.3.2.

\section{Results}

\section{Floristic characterization}

We recorded a total of 410 taxa at the species and subspecies level, namely about $20 \%$ of the flora of the Monti Sibillini National Park (see Ballelli et al., 2010). Eight species were new for the National Park.

Achillea tomentosa L., Calluna vulgaris (L.) Hull and Genista sagittalis L. are among the taxa of highest conservation interest (Table S1). The most represented chorological groups were Mediterranean (135 taxa, 32.9\%),
Eurasian (115; 28.0\%), and European (58; 14.1\%), followed by taxa with a wide distribution (44; 10.7\%), boreal (27; 6.6\%), endemic (17; 4.1\%), and Atlantic (6; $1.5 \%)$. The number of taxa with undetermined distribution was 8 (2\%) (Table S2).

\section{Phytosociological and ecological characterization of plant communities}

The cluster analysis of the phytosociological relevés separated three main groups (Figure 2).

Cluster A (Table 1) grouped dwarf shrub and herbaceous communities growing at higher altitudes (Table S3). It was dominated by species of classes Festuco-Brometea, Festuco hystricis-Ononidetea striatae, and Elyno-Seslerietea $(32.0 \%)$ and class Nardetea (28.3\%) (Table 2). The constant species were fewer than in the other clusters; the most frequent were Nardus stricta, Brachypodium rupestre, Luzula multiflora subsp. multiflora, Helianthemum nummularium subsp. obscurum, and Cruciata glabra (Table S4). Nardus scricta, Luzula multiflora subsp. multiflora, Genista sagittalis, Thesium linophyllon, Brachypodium rupestre, Trifolium montanum subsp. rupestre, and Cruciata glabra, were the main indicator species (Table S5). Cluster A was divided into two sub-clusters (Figure 2, Table 1) dominated by Calluna vulgaris $\left(\mathrm{A}_{1}\right)$ and Nardus stricta $\left(\mathrm{A}_{2}\right)$. In the first sub-cluster, the highest cover value was due to the Calluno-Ulicetea species (87.5\%); in the second, Festuco-Brometea, Festuco-Ononidetea, ElynoSeslerietea, and Nardetea species were the most abundant (67\% in total) (Table 2).

Cluster B (Table 3) included herbaceous communities characterized by lower altitude (748 $\mathrm{m}$ a.s.l.), steeper $\left(19.4^{\circ}\right)$ and south-facing slopes $\left(139^{\circ}\right)$ (Table S3). It was dominated by species of the classes Festuco-Brometea, Festuco hystricis-Ononidetea striatae, and Elyno-Seslerietea $(50.6 \%)$, with a conspicuous contribution of species of the class Nardetea (33.1\%) (Table 2). The most abundant species were Bromopsis erecta and Achillea tomentosa. The most frequent constant species were Bromopsis erecta, Achillea tomentosa, Dactylis glomerata, Plantago lanceolata, Hypericum perforatum, Linum usitatissimum subsp. angustifolium, Lysimachia arvensis, Artemisia alba, Vulpia myuros, Trifolium scabrum, T. campestre, Poterium sanguisorba subsp. balearicum (Table S4). The main indicator species were Achillea tomentosa, Lysimachia arvensis, Vulpia myuros, Artemisia alba, Asperula purpurea, Sedum sexangulare, Poterium sanguisorba subsp. balearicum, Trifolium scabrum, and Hypericum perforatum (Table S5). Cluster B was divided into three sub-clusters (Figure 2, 
Figure 2: Dendrogram obtained from the cluster analysis of the "relevés-by-species" matrix.

Slika 2: Dendrogram, narejen s klastersko analizo matrike "popisi x vrste".

A. Group of plant communities of classes CallunoUlicetea and Nardetea strictae: $\mathrm{A}_{1}$. Calluna vulgaris community; $\mathrm{A}_{2}$. Campanulo micranthae-Nardetum strictae. B. Group of plant communities of class Festuco-Brometea: $\mathrm{B}_{1}$. Achillea tomentosa and Trigonella sulcata community; $\mathrm{B}_{2}$. Bromopsis erecta and Achillea tomentosa community with Brachypodium distachyon. $\mathrm{B}_{3}$. Bromopsis erecta and Achillea tomentosa community. C. Group of plant communities of the class Molinio-Arrhenatheretea. $\mathrm{C}_{1}$ Mentho longifoliae-Juncetum inflexi and Deschampsio-Caricetum distantis; $\mathrm{C}_{2}$. Colchico lusitani-Cynosuretum cristati; $\mathrm{C}_{3}$. Ranunculo neapolitani-Arrhenatheretum elatioris ranunculetosum neapolitani.
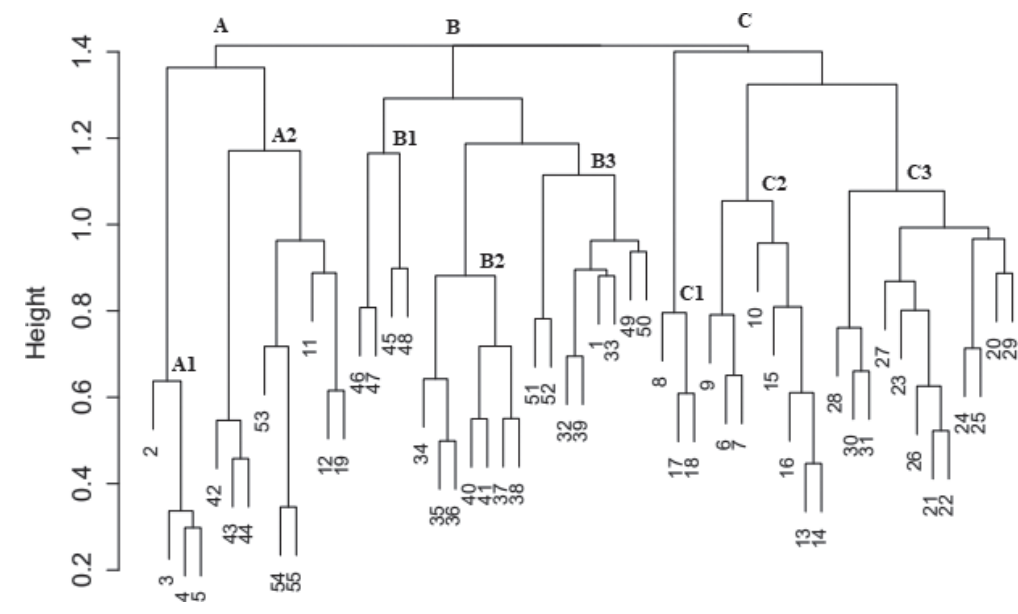

Table 3) dominated by Achillea tomentosa and Trigonella sulcata $\left(\mathrm{B}_{1}\right)$, Bromopsis erecta and Achillea tomentosa $\left(\mathrm{B}_{3}\right)$, Bromopsis erecta and Achillea tomentosa with Brachypodium distachyon $\left(\mathrm{B}_{2}\right)$. The community of sub-cluster $\mathrm{B}_{1}$ develops on gentle slopes at the top of thick arenaceous banks with shallow soils and outcropping rocks. Sub-clusters $B_{2}$ and $\mathrm{B}_{3}$ communities develop on arenaceous-pelithic substrates and deeper soils, the former at lower mean altitudes (mean value: $630 \mathrm{~m}$ ) and on south-facing slopes, the latter at higher mean elevations (ca. $870 \mathrm{~m}$ ), on less strictly south-facing slopes. Among the three sub-clusters, subcluster $\mathrm{B}_{1}$ had the lowest percentage of Festuco-Brometea, Festuco-Ononidetea and Elyno-Seslerietea species; sub-cluster $\mathrm{B}_{2}$ had the highest abundance of therophytic/chamaephytic xerophilous species; sub-cluster $\mathrm{B}_{3}$ had the highest percentage of Festuco-Brometea, Festuco-Ononidetea, and Elyno-Seslerietea and Molinio-Arrhenatheretea species, and the lowest abundance of therophytic/chamaephytic xerophilous species (Table 2).

Cluster C (Table 4) included herbaceous communities that developed on semi-flat $\left(5^{\circ}\right)$, west and east-facing slopes $\left(79^{\circ}\right)$ (Table S3). The cluster was dominated by species of class Molinio-Arrhenatheretea (72.4\%, Table 2). Among the constant species, we found Anthoxanthum odoratum, Arrhenatherum elatius, Dactylis glomerata subsp. glomerata, Holcus lanatus, Rumex acetosa, Trifolium pratense subsp. pratense, and Linum usitatissimum subsp. angustifolium (Table S4). The main indicator species were Trifolium pratense, Holcus lanatus, Lotus corniculatus, Arrhenaterum elatius, Lolium perenne, and Poa trivialis (Table S5).

Cluster $\mathrm{C}$ was divided into four sub-clusters (Figure 2, Table 4) dominated by Juncus inflexus or Deschampsia cespitosa $\left(\mathrm{C}_{1}\right)$, Cynosurus cristatus $\left(\mathrm{C}_{2}\right)$, and Arrhenatherum elatius $\left(\mathrm{C}_{3}\right)$. Sub-cluster $\mathrm{C}_{1}$ had the highest percentages (95\%) of Molinio-Arrhenatheretea species, while cluster $\mathrm{C}_{3}$ had the highest value of companion species (Table 2).

\section{Environmental drivers of plant community distribution and composition}

Altitude, aspect, and slope significantly explained the variance of the species data set (adj. $\left.R^{2}=0.19 ; p=0.001\right)$, both considered together and individually $(p=0.001)$. The first two RDA axes explained the $13 \%$ and the $9 \%$ of the variance $\left(\mathrm{R}^{2} ; p=0.001\right)$. As regards EIVs, we found a significant relation of the species data set with light intensity $\left(\mathrm{R}^{2}=80 \% ; p=0.001\right)$, air temperature $\left(\mathrm{R}^{2}=88 \%\right.$; $p=0.001)$, soil moisture $\left(\mathrm{R}^{2}=63 \% ; p=0.004\right)$, soil nutri-

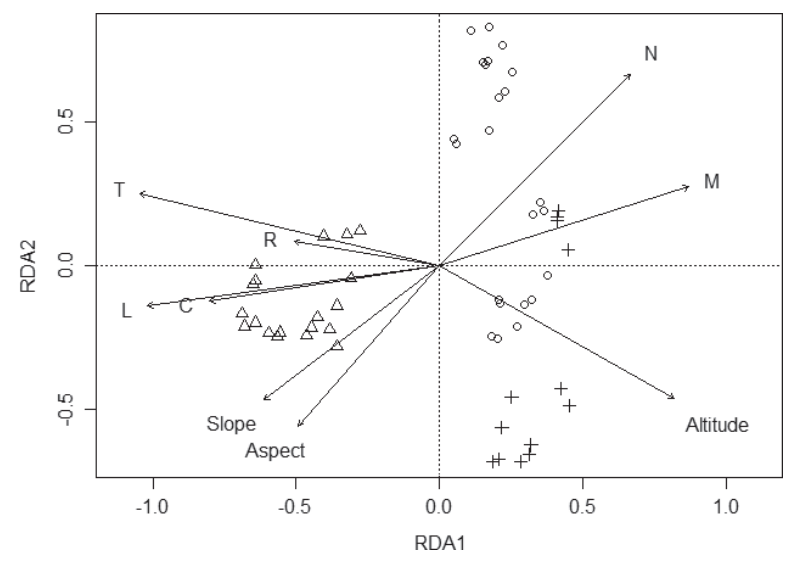

Figure 3: Redundancy analysis (RDA) ordination graph showing the effect of topographic variables on the species cover values (crosses cluster A; triangles - cluster B; and circles - cluster C). Supplementary vectors related to light intensity (L), air temperature (T), Continentality $(\mathrm{C})$, soil moisture $(\mathrm{M})$, soil reaction $(\mathrm{R})$ and soil nutrients $(\mathrm{N})$ are projected onto ordination diagrams.

Slika 3: Ordinacijski graf, narejen z analizo renundance (RDA), kaže pomen topografskih spremenljivk na pokrovnost vrst (križci - klaster A; trikotniki - klaster B; in krožci - klaster C). Dodatni vektorji za svetlobo $(\mathrm{L})$, temperature zraka $(\mathrm{T})$, celinskost $(\mathrm{C})$, vlažnost tal $(\mathrm{M})$, reakcijo tal $(\mathrm{R})$ in hranila $\mathrm{v}$ tleh $(\mathrm{N})$ so pasivno projicirani na ordinacijski diagram. 
ents $\left(\mathrm{R}^{2}=67 \% ; p=0.001\right)$, and continentality $\left(\mathrm{R}^{2}=50 \%\right.$; $p=0.024)$. Nardus stricta and Calluna vulgaris-dominated communities (cluster A) were related to the highest elevations, acidic soils with lower air temperature. The $A r-$ rhenatherum elatius-dominated communities (cluster C) and the Bromopsis erecta-dominated communities (cluster B) were associated with lower elevations (Figure 3). The former was related to flat and semi-flat lands and northfacing slopes, particularly nutrient-rich and moist soils and lower light intensity and air temperature and higher soil nutrients and moisture; the latter was associated with the opposite conditions, i.e., very steep south-facing slopes, higher light intensity and air temperature, and lower soil nutrients and moisture (Figure 3).

\section{Discussion}

\section{Floristic assessment of grasslands}

The floristic research on the grassland communities that develop on non-carbonatic substrates of the Monti Sibillini National Park allowed to highlight the relevance of the study area due to the presence of taxa of high conservation interest, such as Achillea tomentosa (lg. Marchesoni, in Ballelli et al., 2005), Astrantia major subsp. involucrata (lg. Ricci, in Paolucci, 1890, lg. Marchesoni, in Ballelli et al., 2005), Cardamine apennina (lg. Marchesoni, in Lihova' et al., 2004; Ballelli et al., 2005), Carum carvi (lg. Marchesoni, in Ballelli et al., 2005), Crepis aurea subsp. glabrescens (lg. Marchesoni, in Ballelli et al., 2005), Genista sagittalis subsp. sagittalis (Ballelli et al., 2005; Ballelli et al., 2010), Gentiana dinarica (lg. Marchesoni, in Ballelli et al. 2005), Traunsteinera globosa (lg. Marchesoni, in Marchesoni, 1959; Ballelli et al., 2005), Vaccinium myrtillus (lg. Marchesoni, in Marchesoni, 1959; Ballelli et al., 2005), Erica scoparia subsp. scoparia (Brilli-Cattarini \& Ballelli, 1979), Serapias lingua (Bertoloni, 1833-54; Servilli \& Dell'Orsoc, 2000; lg. Marchesoni, in Ballelli et al., 2005; Benigni et al., 2011), Astragalus danicus (Ballelli, 2003, lg. Marchesoni, in Ballelli et al., 2005), Carex leporina (lg. V. Marchesoni, in Ballelli et al., 2005), Dichoropetalum carvifolium-chabraei (Bertoloni, 1837; Sanguinetti, 185267; Caruel, 1888; Paolucci, 1890; Ballelli \& Francalancia, 1995), Juncus capitatus (lg. Marzialetti, in Paolucci, 1890), Oxytropis pilosa subsp. caputoi (Brilli-Cattarini \& al., 2001, lg. V. Marchesoni in Ballelli et al., 2005), Sanguisorba officinalis (lg. V. Marchesoni, in Ballelli et al., 2005), and Viola canina subsp. canina (sub V. canina subsp. ruppii, lg. V. Marchesoni, in Ballelli et al., 2005).

At the edge of the forest, on the western side of Mount Oialona, there is a small population of Calluna vulgaris (Brilli-Cattarini \& Ballelli, 1979) linked to acidic or cal- careous strongly decalcified soils. The Mount Oialona is the southernmost site of its distribution range in Italy.

The botanical relevance in the study area is also due to the presence of a ditch, which hosts some rare or uncommon species in the Marche region, such as Carex panicea (Brilli-Cattarini \& Ballelli, 1979) and Equisetum palustre. Other noteworthy species are Hordeum secalinum, Carex distans, C. pallescens, Ophioglossum vulgatum, and Parnassia palustris. In particular, Ophioglossum vulgatum is a rare circumboreal species, growing in humid meadows and underwoods, especially in periodically flooded places (Ballelli et al., 2005; Ballelli et al., 2010).

A total of eight new plant species were discovered that have not been previously reported by other authors for the Sibillini National Park. Specifically, the new species are: Jacobaea erucifolia s.l., Diplotaxis muralis, Myagrum perfoliatum, Silene vulgaris subsp. tenoreana, Onobrychis caput-galli, Misopates orontium, Potentilla pedata, and Thymelaea passerina.

\section{Phytosociological and ecological interpretation of plant communities}

The phytosociological interpretation of plant communities highlighted by cluster analysis (Figure 2) led to the identication of nine communities, which were classified in four phytosociological classes, as highlighted in the following syntaxonomic scheme.

CALLUNO VULGARIS-ULICETEA MINORIS Br.-Bl.

\& Tüxen ex Klika in Klika \& Hadač 1944

VACCINIO MYRTILLI-GENISTETALIA PILOSAE

Schubert ex Passarge 1964

Genisto pilosae-Vaccinion uliginosi $\mathrm{Br}$-Bl. 1926

Calluna vulgaris community

NARDETEA STRICTAE Rivas Goday in Rivas Goday

\& Rivas-Martínez 1963

NARDETALIA STRICTAE Oberdorfer ex Preising 1949

Ranunculo pollinensis-Nardion strictae Bonin 1972

Campanulo micranthae-Nardetum strictae Biondi \& Galdenzi 2012 nardetosum strictae

FESTUCO VALESIACAE-BROMETEA ERECTI Br.-Bl. \& Tüxen ex Soó 1947

PHLEO AMBIGUI-BROMETALIA ERECTI Biondi, Allegrezza, Blasi \& Galdenzi in Biondi, Allegrezza, Casavecchia, Galdenzi, Gasparri, Pesaresi, Vagge \& Blasi 2014 Achillea tomentosa and Trigonella sulcata community Bromopsis erecta and Achillea tomentosa community Bromopsis erecta and Achillea tomentosa community with Brachypodium distachyon 
MOLINIO-ARRHENATHERETEA Tüxen 1937

TRIFOLIO-HORDEETALIA Horvatić 1963

Ranunculion velutini Pedrotti 1978

Deschampsio-Caricetum distantis Pedrotti 1976

TRIFOLIO REPENTIS-PHLEETALIA PRATENSIS

Passarge 1969

Cynosurion cristati Tüxen 1947

Colchico lusitani-Cynosuretum cristati Biondi \& Ballelli 1995

ARRHENATHERETALIA ELATIORIS Tüxen 1931

Ranunculo neapolitani-Arrbentatherion elatioris Allegrezza \& Biondi 2011

Ranunculo neapolitani-Arrhentatheretum elatioris Allegrezza \& Biondi 2011

ranunculetosum neapolitani Allegrezza \& Biondi 2011

POTENTILLO-POLYGONETALIA AVICULARIS

Tüxen 1947

Mentho longifoliae-Juncion inflexi T. Müller et Görs ex de Foucault 2009

Mentho longifoliae-Juncetum inflexi Lohmeyer ex Oberdorfer 1957

The communities of cluster A, assigned to the Nardetea strictae and Calluno-Ulicetea classes, were the most acidophilous and were found at higher elevations. The values of light intensity, air temperature, soil nitrogen, and soil moisture were intermediate between the grasslands of clusters B and C. The communities of cluster B, classified as Festuco-Brometea class, were found on steeper, southfacing slopes and had higher values for light intensity and air temperature and lower values for soil nutrients and moisture. The grassland communities of cluster $\mathrm{C}$, attributed to the Molinio-Arrhenatheretea class, were clearly associated with altitude and slope (mainly low altitudes and gentle slopes or semi-flat lands), and high soil nutrient and moisture values.

Group of ACidophilous communities of the MOUNTAIN BELT, CHARACTERIZED BY CALLUNA VULGARIS or Nardus StRICTA (Cluster A, TABle 1)

\section{Calluna vulgaris community (cluster A, Table 1, rel. 1-4)}

Species-poor community of acidophilous shrublands at $1100-1150 \mathrm{~m}$ a.s.l., physiognomically characterized by Calluna vulgaris, with Vaccinium myrtillus. The occurrence of $C$. vulgaris, V. myrtillus, and Erica scoparia subsp. scoparia, justifies a classification of the community in the Genisto pilosae-Vaccinion uliginosi alliance (order Vaccinio myrtilli-Genistetalia pilosae, class Calluno-Ulicetea). However, due to the small number of species and the small surface area occupied, there are no elements to describe a new association or identify an oldest one.
This community differs from the Danthonio-Callunetum association described by Pedrotti (1982) in the basin of Lake Trasimeno and from the Tuberario lignosae-Callunetum (Pedrotti, 1982) by the absence of Genista germanica, G. pilosa, Cytisus scoparius, and Danthonia decumbens and of Mediterranean species, and by the presence of Vaccinium myrtillus.

This community is in serial contact with the beech forests of the Solidagini-Fagetum sylvaticae association (see Catorci et al., 2008).

\section{Campanulo micranthae-Nardetum strictae Biondi et Galdenzi 2012 (cluster A, Table 1, rel. 5-13)}

Community of acidophilous mountain grasslands with dense swards, widespread in slightly to moderately steep areas located on the top of the highest hills with acid soils due to the occurence of sandstone banks. Physiognomically it is characterized by Nardus stricta, with elements of the Ranunculo-Nardion alliance, Nardetalia strictae order, and Nardetea strictae class, such as Potentilla rigoana, P. erecta, Ranunculus pollinensis, R. apenninus, and Avenella flexuosa. The presence of species Campanula micrantha, Silene ciliata subsp. graefferi, Luzula multiflora, Agrostis capillaris, and Cynosurus cristatus indicates that the community fits the Campanulo-micranthae-Nardetum strictae association. This association was described by Biondi \& Galdenzi (2012) in the nearby Montagna dei Fiori (Marche).

This association is in serial contact with the beech forests of the association Solidagini-Fagetum sylvaticae (see Catorci et al., 2008).

Group of Plant Communities of the FESTUCO-

BROMETEA CLASS, CHARACTERIZED BY ACHILLEA TOMENTOSA (CLUSTER B, TABLE 3)

On the arenaceous and arenaceous-pelithic substrates up to $1000 \mathrm{~m}$ a.s.l., we found a group of three plant communities characterized by Achillea tomentosa, following an aridity gradient, from the open-turf community of the shallow arenaceous soils to the closed-turf community of deeper soils on arenaceous-pelithic substrates. Probably, these plant communities can be interpreted as facets of an association developed on a broader geographical range and ecological conditions, which should be investigated in more detail and in larger areas. For this reason, we preferred to avoid syntaxonomic classification at the level of association and the alliance.

\section{Achillea tomentosa and Trigonella sulcata community (cluster B, Table 3, rel. 1-4)}

An open-turf community that occurs on shallow soils with outcropping arenaceous rocks, on gentle slopes that tend to be north-facing, at $700-750 \mathrm{~m}$. The total veg- 
etation cover is approximately $80 \%$. It is physiognomically characterized by Achillea tomentosa and a group of therophytes and chamaephytes such as Trigonella sulcata, Petrorhagia saxifraga, Arenaria leptoclados, Trifolium angustifolium subsp. angustifolium, T. arvense, Ononis reclinata, Sabulina mediterranea, S. tenuifolia, Micromeria graeca, Linum strictum, and Teucrium capitatum subsp. capitatum. Despite the presence of a conspicuous set of species from Stipo-Trachynietea, Helianthemetea guttati, and Sedo-Schleranthetea, the structure of the community is dominated by species from class Festuco-Brometea such as Bromopsis erecta, Phleum hirsutum subsp. ambiguum, Brachypodium rupestre, Achillea tomentosa, and Asperula purpurea, leading us to classify this community within the class Festuco-Brometea.

This community is in serial contact with the hop-hornbeam and turkey oak woodlands of the Aceri obtusatiQuercetum cerridis association (Catorci et al., 2008).

\section{Bromopsis erecta and Achillea tomentosa community (cluster B, Table 3, rel. 12-19)}

Community of south-facing slopes, which develops at 650-1000 m on arenaceous-pelithic substrates with deeper soils. It is physiognomically characterized by Bromopsis erecta and Achillea tomentosa with, in suborder, Carex caryophyllea, Thymus moesiacus, Linum catharticum, and Sedum sexangulare. The prevalence of the species of Festuco-Brometea justifies the classification of this community in the class Festuco-Brometea.

The Bromopsis erecta and Achillea tomentosa community is in serial contact with the beech forests of the Erico arboreae-Quercetum pubescentis quercetosum cerridis subassociation (Catorci et al., 2008).

\section{Bromopsis erecta and Achillea tomentosa community with Brachypodium distachyon (cluster B, Table 3,} rel. 5-11)

Community of south-facing slopes, spreading at 500$750 \mathrm{~m}$ on arenaceous-pelithic substrates. It differes from the previous community by a group of therophytic species consisting of Brachypodium distachyon, Briza minor, Gastridium ventricosum, Euphorbia exigua subsp. exigua, Crepis neglecta, Galium parisiense, and Helianthemum salicifolium.

This community is in serial contact with the white oak woodlands of the Erico arboreae-Quercetum pubescentis ericetosum arboreae subassociation (Catorci et al., 2008).

Group of plant communities of the MolinioARRHENATHERETEA CLASS, CHARACTERIZED BY ARRHENATHERUM ELATIUS AND CYNOSURUS CRISTATUS (CLUSTer C, Table 4)

Mesophilous or hygrophilous grasslands with a dense sward, spreading on flat or semi-flat lands on alluvial sub- strates and detritic material, at the edge of ditches and depressions.

\section{Mentho longifoliae-Juncetum inflexi Lohmeyer ex Oberdorfer 1957 (cluster A, Table 4, rel. 1).}

Species-poor sub-nitrophilous and sub-hygrophilous community dominated by Juncus inflexus subsp. inflexus and found along small ditches crossing grasslands dominated by the Cynosurus cristatus. J. inflexus is associated with species of the Potentillo-Polygonetalia order and Molinio-Arrhenateretea class, e.g. Ranunculus repens, Carex hirta, Galium album subsp. album, Rumex acetosa, Lolium arundinaceum, Poa trivialis, and Lychnis flos-cuculi. The species composition of the community allows us to classify it in the Potentillo-Polygonetalia order of the Molinio-Arrhenateretea class. Because of the dominance of the helophyte Juncus inflexus subsp. inflexus and the presence of Mentha longifolia, we assigned this community to the Mentho longifoliae-Juncetum inflexi, which occurs from northern Italy (e.g. Andreis et al., 1995; Tomasi \& Caniglia, 2004) to central and southern Italy (e.g. Canullo et al., 1988; Pirone, 2000; Pirone et al., 2004). The species composition of this community differs from that of Galio palustris-Juncetum inflexi, described by Venanzoni \& Gigante (2000), because of the absence of Galium palustre and Scutellaria galericulata and the prevalence of species of the Molinio-Arrhenatheretea class. It also differs from the Carici otrubae-Juncetum inflexi Minissale et Spampinato 1985 asssociation because Carex otrubae, characteristic of the association, is absent.

\section{Deschampsio-Caricetum distantis Pedrotti 1976 (cluster C, Table 4, rel. 2-3)}

Thick-sward wet meadows, dominated by Deschampsia cespitosa, found in depressions that are flooded in early summer and moist by the end of summer. This community includes numerous elements of the Molinio-Arrhenatetetea class (e.g. Poa trivialis, Centaurea jacea subsp. jacea, Rumex acetosa subsp. acetosa, and Ranunculus acris). The presence of Lolium arundinaceum subsp. arundinaceum, justifies the classification of the community in the Ranunculion velutini alliance of the order TrifolioHordeetalia. The occurrence of Carex distans, next to Deschampsia cespitosa, allows its assignment to the association Deschampsio-Caricetum distantis, described by Pedrotti (1976) in the Piani di Montelago (Marche). The association is endemic to the wet meadows of central and southern Italy (Pedrotti, 1975; Pedrotti, 1976; Canullo et al., 1988; Pedrotti et al., 1992; Pirone, 1997; Catorci \& Orsomando, 2001; Tardella et al., 2002; Tardella \& Di Agostino, 2020). 


\section{Colchico lusitani-Cynosuretum cristati Biondi et Ballelli 1995 (cluster C, Table 4, rel. 4-11)}

Community of mesophilous hay meadows with a dense sward, in areas covered by detritic material. It is physiognomically characterized by Cynosurus cristatus with numerous elements of the Molinio-Arrhenatheretea class.

The presence of Lolium perenne, Bellis perennis, Phleum pratense subsp. pratense, and Trifolium repens allows to classify this community in the order Trifolio repentisPhleetalia pratensis and alliance Cynosurion cristati. More specifically, the community found in the study area fits with the Colchico lusitani-Cynosuretum cristati association, described by Biondi \& Ballelli (1995) in the humid hay-meadows of the Coscerno-Civitella massif (Umbria) due to the occurrence of the characteristic species Colchicum lusitanum, Achillea millefolium, and Tragopogon pratensis subsp. pratensis, besides Cynosurus cristatus, and a conspicuous group of Festuco-Brometea species.

This community differs from the Achilleo collinae-Cynosuretum cristati, described by Biondi et al. (1989) for the arenaceous substrates in the district Monte Catria-Nerone by the absence of the characteristic species Phleum pratense subsp. bertolonii and Lotus tenuis, as well as most of the differential species of the association in comparison with the Cynosurus cristatus-dominated communities of the calcareous Apennine ridges (e.g. Ononis spinosa, Scabiosa columbaria, Eryngium amethystinum, Ziziphora granatensis subsp. alpina, Clinopodium vulgare, Dorycnium pentaphyllum, Blackstonia perfoliata and Carthamus lanatus). The community differs from the Campanulo glomeratae-Cynosuretum cristati association, described by Ubaldi et al. (1987) by the absence of Campanula glomerata, Armeria canescens, Rumex acetosa, Taraxacum officinale, Geranium pyrenaicum, Cruciata laevipes, Helichtotrichon praetutianum, Scorzoneroides cichoraceus, Orchis mascula and Veronica serpyllifolia.

This association is in serial contact with the beech forests of the association Solidagini-Fagetum sylvaticae (Catorci et al., 2008).

\section{Ranunculo neapolitani-Arrbenatheretum elatioris Allegrezza et Biondi 2011 ranunculetosum neapolitani Allegrezza et Biondi 2011 (cluster C, Table 4, rel. 12-23)}

Community of mesophilous hay-meadows with a dense sward, spread on alluvial substrates, physiognomically characterized by Arrhenatherum elatius, with a dominance of species of the class Molinio-Arrhenatheretea. The occurrence of Ranunculus neapolitanus, Pastinaca sativa subsp. urens, and Achillea collina justifies a classification of the community in the Ranunculo neapolitani-Arrhenatherion elatioris alliance, while Holcus lanatus subsp. lanatus, Tragopogon pratensis subsp. orientalis, Salvia pratensis, Trifolium campestre, Geranium dissectum, Galium mollugo, Trisetaria flavescens, Cynosurus cristatus, and Colchicum lusitanum are characteristic taxa of the Ranunculo neapolitani-Arrhenatheretum elatioris association with the typical subassociation ranunculetosum neapolitani.

This community was described by Allegrezza \& Biondi (2011), who referred to this subassociation the relevés carried out by Pedrotti (1963) and Venanzoni (1992) in the Nera and Velino basins.

This community is in serial contact with the forests of the Aceri obtusati-Quercetum cerridis fagetosum sylvaticae sub-association (Catorci et al., 2008).

\section{Conclusion and conservation remarks}

The study presented here has highlighted how the sectors of the Sibillini National Park with non-calcareous substrates are essential for the implementation of the biodiversity of the protected area. In fact, communities such as the arid ones with Achillea tomentosa or the formations dominated by Arrhenatherum elatius are not present on the carbonate mountains. The Nardus stricta-dominated grasslands are also extremely interesting, as they occur elsewhere only on small areas and probably with a partially different floristic composition. However, the general conservation status of such grasslands is rather low, at least as regards the Nardus stricta and the Achillea tomentosa vegetation types, which are no longer in agricultural land use and are therefore subject to species turnover and invasion by shrubs and pre-forest formations. Even the conservation status of the dwarf shurbland dominated by Calluna vulgaris, is very precarious, as they are fragmented formations rather than true heath formations. Finally, the contribution to the flora of the National Park is also relevant, as eight (8) new species have been discovered in addition to the approximately 2000 currently known (Ballelli et al., 2010).

Tardella Federico Maria (1) https://orcid.org/0000-0002-4319-9131 Pennesi Riccardo (1) https://orcid.org/0000-0002-6145-5581 Panichella Tiziana (1) https://orcid.org/0000-0002-3638-8110 Bricca Alessandro (1) https://orcid.org/0000-0003-0202-6776 Catorci Andrea (1) https://orcid.org/0000-0001-9012-7635 


\section{References}

Allegrezza, M., Ballelli, S., \& Giammarchi, F. (2007). Gli Habitats d'interesse Comunitario nell'anfiteatro montuoso della Valle della Corte (Monti della Laga-Appennino centrale). Fitosociologia, 44(2), $133-140$.

Allegrezza, M., \& Biondi, E. (2011). Syntaxonomic revision of the Arrhenatherum elatius grasslands of central Italy. Fitosociologia, 48(1), 23-40.

Allegrezza, M., Ballelli, S., Mentoni, M., Olivieri, M., Ottaviani, C., Pesaresi, S., \& Tesei, G. (2013). Biodiversity in the Sibillini Mountain range (Sibillini National Park, central Apennines): the example of Piè Vettore. Plant Sociology, 50, 57-89. https://doi.org/10.7338/ pls2013501/06

Amici, M., \& Spina, R. (2002). Campo medio della precipitazione annuale e stagionale sulle Marche per il periodo 1950-2000. Centro di Ecologia e Climatologia, Osservatorio Geofisico Sperimentale Macerata.

Andreis, C., D’Auria, G., \& Zavagno, F. (1995). La vegetazione alveale del tratto terminale del F. Brembo in relazione a morfologia e substrato. Giornale Botanico Italiano, 129(2), 264.

Antrop, M. (2004). Landscape change and the urbanization process in Europe. Landscape and Urban Planning, 67, 9-26. https://doi. org/10.1016/S0169-2046(03)00026-4

Anzalone, B., Iberite, M., \& Lattanzi, E. (2010). La flora vascolare del Lazio. Informatore Botanico Italiano, 42(1), 187-317.

ASSAM (Agenzia Servizi Settore Agroalimentare delle Marche) (2006). Suoli e Paesaggi delle Marche. Errebi Grafiche Ripesi, Falconara Marittima.

Ballelli, S. (2003). Aggiornamento delle conoscenze sulla Flora dell'Umbria. Webbia, 58 (1), 1-55. https://doi.org/10.1080/0083779 2.2003.10670743

Ballelli, S., \& Allegrezza, M. (2016). New records for the Laga Mountains (Marche, Abruzzo, Lazio) and the central Apennines. Webbia, 71(1), 127-139. https://doi.org/10.1080/00837792.2016.1138203

Ballelli, S., \& Bellomaria, B. (2005). La flora officinale delle Marche. Volumi 1-2. L'uomo e l'ambiente, 43, 3-1000.

Ballelli, S., \& Francalancia, C. (1995). Siti di interesse comunitario nei nuovi parchi nazionali dell'Appennino centrale. Vegetazione e flora Monti Sibillini e Monti della Laga. Applicazione della direttiva habitat 92/43/ CEE nei parchi nazionali dei Monti Sibillini, del Gran Sasso-Monti della Laga e della Majella. European Commission, Ministero dell'Ambiente Servizio Conservazione della Natura.

Ballelli, S., Cesaretti, S., Gatti, R., Montenegro, B.F., Vitanzi, A., \& Catorci A. (2010). Catalogo della flora vascolare dei Monti Sibillini (Appennino centrale - Italia). Braun-Blanquetia, 47, 1-122.

Ballelli, S., Gatti, R., Raponi, M., \& Catorci, A. (2006). Aspetti vegetazionali e floristici del territorio nursino (Umbria-Italia centrale): le serie di vegetazione della roverella (Quercus pubescens s.l.). Webbia, 61(2), 305-323. https://doi.org/10.1080/00837792.2006.1 0670808

Ballelli, S., Lucarini, D., \& Pedrotti, F. (2005). Catalogo dell'erbario dei Monti Sibillini di Vittorio Marchesoni. Braun-Blanquetia, 38, 3-259.
Bartolucci, F., Domina, G., Alessandrini, A., Angiolini, C., Ardenghi, N.M.G., Bacchetta, G., Banfi, E., Bolpagni, R., Bonari, G., Bräuchler, C., Calvia, G., Cancellieri, L., Cannucci, S., Carruggio, F., Conti, F., Cavallaro, V., Fanfarillo, E., Ferretti, G., Festi, F., Fiaschi, T., Foggi, B., Forte, L., Fröhner, S.E., Galasso, G., Gestri, G., Gottschlich, G., Labadessa, R., Lastrucci, L., Lazzaro, L., Mereu, G., Morabito, A., Mugnai, M., Musarella, C.M., Orsenigo, S., Pazienza, G., Pennesi, R., Peruzzi, L., Pierini, B., Podda, L., Prosser, F., Rossi, G., Scoppola, A., Spampinato, G., Stinca, A., Tomaselli, V., Zangari, G., \& Nepi, C. 2019a. Notulae to the Italian native vascular flora: 7. Italian Botanist, 7, 125-148. https://doi.org/10.3897/italianbotanist.7.36148

Bartolucci, F., Domina, G., Ardenghi, N.M.G., Bacaro, G., Bacchetta, G., Ballarin, F., Banfi, E., Barberis, G., Beccarisi, L., Bernardo, L., Bonari, G., Bonini, F., Brullo, S., Buono, S., Buono, V., Calbi, M., Caldararo, F., Calvia, G., Cancellieri, L., Cannavò, S., Dagnino, D., Esposito, A., Fascetti, S., Filibeck, G., Fiorini, G., Forte, L., Galasso, G., Gestri, G., Gigante, D., Gottschlich, G., Gubellini, L., Hofmann, N., Lastrucci, L., Lonati, M., Lorenz, R., Lunardi, L., Magrini, S., Mainetti, A., Maiorca, G., Mereu, G., Messa Ballarin, R.T., Minuto, L., Mossini, S., Musarella, C.M., Nimis, P.L., Passalacqua, N.G., Peccenini, S., Petriglia, B., Podda, L., Potenza, G., Ravetto Enri, S., Roma-Marzio F., Rosati, L., Ruggero, A., Spampinato, G., Stinca, A., Tiburtini, M., Tietto, C., Tomaselli, V., Turcato, C., Viciani, D., Wagensommer, R.P., \& Nepi, C. 2019b. Notulae to the Italian native vascular flora: 8. Italian Botanist, 8, 95-116. https://doi.org/10.3897/italianbotanist.8.48626

Bartolucci, F., Domina, G., Ardenghi, N.M.G., Bacchetta, G. Bernardo, L., Buccomino, G., Buono, S., Caldararo, F., Calvia, G., Carruggio, F., Cavagna, A., D’Amico, F.S., Di Carlo, F., Festi, F., Forte, L., Galasso, G., Gargano, D., Gottschlich, G., Lazzaro, L., Magrini, S., Maiorca, G., Medagli, P., Mei, G., Mennini, F., Mereu, G., Miserocchi, D., Olivieri, N., Passalacqua, N.G., Pazienza, G., Peruzzi, L., Prosser, F., Rempicci, M., Roma-Marzio, F., Ruggero, A., Sani, A., Saulle, D., Steffanini, C., Stinca, A., Terzi, M., Tondi, G., Trenchi, M., Viciani, D., \& Wagensommer, RP., Nepi, C. (2018a). Notulae to the Italian native vascular flora: 6. Italian Botanist, 6, 45-64. https://doi.org/10.3897/italianbotanist.6.30575

Bartolucci, F., Domina, G., Ardenghi, N.M.G., Banfi, E., Bernardo, L., Bonari, G., Buccomino, G., Calvia, G., Carruggio, F., Cavallaro, V., Chianese, G., Conti, F., Facioni, L., Del Vico, E., Di Gristina, E., Falcinelli, F., Forte, L., Gargano, D., Mantino, F., Martino, M., Mei, G., Mereu, G., Olivieri, N., Passalacqua, N.G., Pazienza, G., Peruzzi, L., Roma-Marzio, F., Scafidi, F., Scoppola, A., Stinca, A., \& Nepi, C. (2018b). Notulae to the Italian native vascular flora: 5. Italian Botanist, 5, 71-81. https://doi.org/10.3897/italianbotanist.5.25892

Bartolucci, F., Peruzzi, L., Galasso, G., Albano, A., Alessandrini, A., Ardenghi, N.M.G., Astuti, G., Bacchetta, G., Ballelli, S., Banfi, E., Barberis, G., Bernardo, L., Bouvet, D., Bovio, M., Cecchi, L., Di Pietro, R., Domina, G., Fascetti, S., Fenu, G., Festi, F., Foggi, B., Gallo, L., Gottschlich, G., Gubellini, L., Iamonico, D., Iberite, M., Jiménez-Mejías, P., Lattanzi, E., Marchetti, D., Martinetto, E., Masin, R.R., Medagli, P., Passalacqua, N.G., Peccenini, S., Pennesi, R., Pierini, B., Poldini, L., Prosser, F., Raimondo, F.M., Roma-Marzio, F., Rosati, L., Santangelo, A., Scoppola, A., Scortegagna, S., Selvaggi, A., Selvi, F., Soldano, A., Stinca, A., Wagensommer, R.P., Wilhalm, T., \& Conti, F. (2018c). An updated checklist of the vascular flora native to Italy. Plant Biosystems, 152(2), 179-303. https://doi.org/10.1080/1126 3504.2017 .1419996

Bartolucci, F., Ranalli, N., Bouvet, D., Cancellieri, L., Fortini, P., Gestri, G., Di Pietro, R., Lattanzi, E., Lavezzo, P., Longo, D., Marsili, S., Peccenini, S., Prtuzzi, L., Salerno, G., Soldano, A., Tilia, A., Turcato, C., Viciani, D., Wagensommer, R. P., \& Conti, F. (2012). Contributo alla conoscenza floristica del settore settentrionale del Gran Sasso d'Italia (Parco Nazionale del Gran Sasso e Monti della Laga) (Abruzzo): resoconto dell'escursione del Gruppo di Floristica (SBI) nel 2010. Informatore Botanico Italiano, 44(2), 355-385. 
Benigni, F., Petroselli, M., \& Barigelli, G. (2011). Segnalazione di Serapias lingua L. in provincia di Ascoli Piceno (Marche). GIROS Notizie, 48, 40.

Bertoloni, A. (1833). Flora italica, sistens plantas in Italia et in insulis circumstantibus sponte nascentes 1(2). Ex Typographaeo Riccardo Masi.

Bertoloni, A. (1837). Flora italica, sistens plantas in Italia et insulis circumstantibus sponte nascentes 3. Riccardo Masi.

Bertoloni, A. (1853). Flora Italica 9. Riccardo Masi.

Biondi, E., \& Ballelli, S. (1995). Le praterie del Monte Coscerno e Monte di Civitella (Appennino umbro-marchigiano -Italia centrale). Fitosociologia, 30, 91-121.

Biondi, E., \& Blasi, C. (2015). Prodromo della vegetazione d'ttalia. Retrieved from http://www. prodromo-vegetazioneitalia. org.

Biondi, E., \& Galdenzi, D. (2012). Phytosociological analysis of the grasslands of Montagna dei Fiori (central Italy) and syntaxonomic review of the class Festuco-Brometea in the Apennines. Plant Sociology, 49(1), 91-112. https://doi.org/10.7338/pls2012491/05

Biondi, E., Ballelli, S., Allegrezza, M., Taffetani, F., \& Guitian, J. (1989). La vegetazione del territorio della Comunita`Montana. In C. Cassano \& F. Pennacchi (Eds.), Sistemi agricoli marginali. Lo scenario della Comunita’ Montana Catria-Nerone (pp. 199-223). Tipolitografia Porziuncola.

Biondi, F., Kozubowski, T. J., \& Panorska, A. K. (2005). A new mode for quantifying climate episodes. International Journal of Climatology: A Journal of the Royal Meteorological Society, 25(9), 1253-1264. https:// doi.org/10.1002/joc.1186

Bracchetti, L., Carotenuto, L., \& Catorci, A. (2012). Land-cover changes in a remote area of central Apennines (Italy) and management directions. Landscape and Urban Planning, 104, 157-170. https://doi. org/10.1016/j.landurbplan.2011.09.005

Braun-Blanquet, J. (1964). Pflanzensoziologie. Grundzüge der Vegetationskunde. Springer. https://doi.org/10.1007/978-3-7091-8110-2

Bricca, A., Tardella, F. M., Tolu, F., Goia, I., Ferrara, A., \& Catorci, A. (2020). Disentangling the effects of disturbance from those of dominant tall grass features in driving the functional variation of restored grassland in a Sub-Mediterranean context. Diversity, 12(1), 11. https://doi.org/10.3390/d12010011

Brilli-Cattarini, A. J. (1971). Segnalazione di piante nuove, inedite, o notevoli per la regione marchigiana. II. Plant Biosystems, 105(1), 23-47. https://doi.org/10.1080/11263506909426698

Brilli-Cattarini, A.J. (1956). Rinvenimenti Floristici Marchigiani: Seconda Serie. Plant Biosystem, 63(1), 117-141. https://doi. org/10.1080/11263505609431622

Brilli-Cattarini, A.J., \& Ballelli, S. (1979). Segnalazione di piante nuove, inedite, o notevoli per la regione marchigiana. IV. Giornale Botanico Italiano, 113 (5-6), 327-358. https://doi. org/10.1080/11263507909426410

Brilli-Cattarini, A.J.B., Di Massimo, S., \& Gubellini, L. (2001). Segnalazioni Floristiche Italiane: 1013. Oxytropis pilosa (L.) DC. subsp. caputoi (Moraldo et la Valva) Brilli-Catt., Di Massimo et Gubellini (Leguminosae). Informatore Botanico Italiano, 33(1), 38-39.

Canullo, R., Pedrotti, F., \& Venanzoni, R. (1988). I prati umidi ed inondati dell'alto Trigno (Molise, Italia). Documents Phytosociologiques, $11,583-606$.
Caruel, T. (1888). Apiaceae. In F. Parlatore, \& T. Caruel (Eds.), Flora italiana. 8. (pp. 179-197). Tip. Le Monnier.

Catorci, A., \& Orsomando, E. (2001). Note illustrative della carta della vegetazione del Foglio Nocera Umbra (N. 312-Carta d'Italia I.G.M. 1:50.000). Braun-Blanquetia, 23, 3-108.

Catorci, A., Biondi, E., Casavecchia, S., Pesaresi, S., Vitanzi, A., Foglia, M., Galassi, M., Pinzi, M., Angelini, E., Bianchelli, M., Ventrone, F., Cesaretti, S., \& Gatti, R. (2007). La Carta della vegetazione e degli elementi di paesaggio vegetale delle Marche (scala 1:50.000) per la progettazione e la gestione della rete ecologica regionale. Fitosociologia, $44(2), 115-118$.

Catorci, A., Vitanzi, A., Paura, B., Iocchi, M., \& Ballelli, S. (2008). La vegetazione forestale dei substrati arenacei della Val d'Aso (Marche, Italia centrale). Fitosociologia, 45(2), 41-7.

Cengia-Sambo, M. (1928). Contributo alla Flora vascolare dell'Urbinate. Nuovo Giornale Botanico Italiano Ns, 35(4), 425-506.

Centamore, E., Pambianchi, G., \& Minetti, A. (1991). Ambiente fisico delle Marche: geologia, geomorfologia, idrogeologia. SELCA.

Conti, F. (1998). An annoted checklist of the flora of the Abruzzo. Bocconea, 10, 1-273.

Conti, F., \& Bartolucci, F. (2016). The vascular flora of Gran Sasso and Monti della Laga National Park (Central Italy). Phytotaxa, 256(1), 1-119. https://doi.org/10.11646/phytotaxa.256.1.1

Cortini Pedrotti, C., Orsomando, E., Pedrotti, F., \& Sanesi, G. (1973). La vegetazione e i suoli del Pian Grande di Castelluccio di Norcia (Appennino centrale). Atti Istituto di Botanica Laboratorio Crittogamico Università di Pavia, 9, 155-249.

Costanzo, L. A., \& MacKay, R. B. (Eds.). (2009). Handbook of research on strategy and foresight. Edward Elgar Publishing.

De Cáceres, M., Legendre, P., Wiser, S. K., \& Brotons, L. (2012). Using species combinations in indicator value analyses. Methods in Ecology and Evolution, 3(6), 973-982. https://doi.org/10.1111/j.2041210X.2012.00246.x

Di Pietro, R. (2007). Coenological and syntaxonomical analysis of the beech woodlands of the Laga Mountains (central Italy). La biogeografia dell'Appennino centrale e settentrionale, 30, 45-118.

Di Pietro, R., Conte, A. L., Di Marzio, P., Fortini, P., Farris, E., Gianguzzi, L., Müller, M., Rosati, L., Spampinato, G., \& Gailing, O., 2021: Does the genetic diversity among pubescent white oaks in southern Italy, Sicily and Sardinia islands support the current taxonomic classification? European Journal of Forest Research, 140(2), 355-371. https://doi.org/10.1007/s10342-020-01334-z

Dufrêne, M., \& Legendre, P. (1997). Species assemblages and indicator species: the need for a flexible asymmetrical approach. Ecological monographs, 67(3), 345-366. https://doi.org/10.1890/00129615(1997)067[0345:SAAIST]2.0.CO;2

Ellenberg, H. (1974). Zeigerwerte der Gefässpflanzen Mitteleuropas. Scripta Geobotanica, 9, 1-97.

Ellenberg, H. (1996). Vegetation Mitteleuropas mit den Alpen. E. Ulmer.

Ellenberg, H., Weber, H. E., Düll, R., Wirth, V., Werner, W., \& Paulißen, D. (1992). Zeigerwerte von Pflanzen in Mitteleuropa. Scripta Geobotanica, 18(2), 1-258. 
Ellenberg, H., Weber, H. E., Düll, R., Wirth, V., Werner, W., \& Paulissen, D. (1991). Zeigerwerte von Pflanzen in Mitteleuropa. Scripta Geobotanica, 18, 1-248.

Falcucci, A., Maiorano, L., \& Boitani, L. (2007). Changes in land-use/ land-cover patterns in Italy and their implications for biodiversity conservation. Landscape ecology, 22(4), 617-631. https://doi. org/10.1007/s10980-006-9056-4

Fiori, A. (1943). Flora Italica Cryptogama. Pars V: Pteridophyta. Società Botanica Italiana.

Francalancia, C., \& Orsomando, E. (1980): Carta della vegetazione del Foglio Spoleto. Consiglio nazionale delle ricerche.

Francalancia, C., Hruska, K., \& Orsomando, E. (1981). Ricerche fitosociologiche sui prati-pascolo di Ragnolo (Appennino centrale). Acta Biologica, 58, 241-253.

Garnier, E., Cortez, J., Billès, G., Navas, M. L., Roumet, C., Debussche, M., Laurent, G., Blanchard, A., Aubry, D., Bellmann, A., Neill, C., \& Toussaint, J. P. (2004). Plant functional markers capture ecosystem properties during secondary succession. Ecology, 85(9), 2630-2637. https://doi.org/10.1890/03-0799

Gigante, D., Attorre, F., Venanzoni, R., Acosta, A. T. R., Agrillo, E., Aleffi, M., Alessi, N., Allegrezza, M., Angelini, P., Angiolini, C., Assini, S., Azzella, M. M., Bagella, S., Biondi, E., Bolpagni, R., Bonari, G., Bracco, F., Brullo, S., Buffa, G., Carli, E., Caruso, G., Casavecchia, S., Casella, L., Cerabolini, B. E. L., Ciaschetti, G., Copiz, R., Cutini, M., Del Vecchio, S., Del Vico, E., Di Martino, L., Facioni, L., Fanelli, G., Foggi, B., Frattaroli, A. R., Galdenzi, D., Gangale, C., Gasparri, R., Genovesi, P., Gianguzzi, L., Gironi, F., Del Galdo, G. G., Gualmini, M., Guarino, R., Lasen, C., Lastrucci, L., Maneli, F., Pasta, S., Paura, B., Perrino, E. V., Petraglia, A., Pirone, G., Poponessi, S., Prisco, I., Puglisi, M., Ravera, S., Sburlino, G., Sciandrello, S., Selvaggi, A., Spada, F., Spampinato, G., Strumia, S., Tomaselli, M., Tomaselli, V., Uzunov, D., Viciani, D., Villani, M., Wagensommer, R. P., \& Zitti, S. L. (2016). A methodological protocol for Annex I Habitats monitoring: the contribution of Vegetation science. Plant Sociology, 53(2), 77-87. https://doi.org/10.7338/pls2016532/06

Godefroid, S., \& Dana, E. D. (2007). Can Ellenberg's indicator values for Mediterranean plants be used outside their region of definition? Journal of Biogeography, 34(1), 62-68. https://doi.org/10.1111/j.13652699.2006.01582.x

Guarino, R., Domina, G., \& Pignatti, S. (2012). Ellenberg's Indicator values for the Flora of Italy - first update: Pteridophyta, Gymnospermae and Monocotyledoneae. Flora Mediterranea, 22, 197-209. https://doi.org/10.7320/FlMedit22.197

Klaus, V. H., Kleinebecker, T., Boch, S., Müller, J., Socher, S. A., Prati, D., Fisher, M., \& Hölzel, N., 2012: NIRS meets Ellenberg's indicator values: Prediction of moisture and nitrogen values of agricultural grassland vegetation by means of near-infrared spectral characteristics. Ecological Indicators, 14(1), 82-86. https://doi.org/10.1016/j. ecolind.2011.07.016

Kowarik, I., \& Seidling, W. (1989). The use of Ellenberg's indicator values - problems and restrictions of the method. Landschaft und Stadt, 21, 132-143.

Lihovà, J., Tribsch, A., \& Stuessy, T. F. (2004). Cardamineapennina: a new endemic diploid species of the $C$. pratensis group (Brassicaceae) from Italy. Plant Systematics and Evolution, 245(1), 69-92. https://doi. org/10.1007/s00606-003-0119-6
Marchesoni, V. (1959). Importanza del fattore storico-climatico e dell'azione antropica nell'evoluzione della vegetazione forestale dell'Appennino Umbro-Marchigiano. Annali Accademia Italiana di Scienze Forestali, 8, 327-343.

Matteucci, D. (1893). Il Monte Nerone e la sua flora. Bullettino della Società Botanica Italiana, 3, 173-180.

Mazzoleni, S., di Pasquale, G., Mulligan, M., di Martino, P., \& Rego, F. (Eds.) (2004). Recent dynamics of the Mediterranean vegetation and landscape. Wiley \& Sons Ltd.

McCune, B., \& Grace, J.B. (2002). Analysis of Ecological Communities. MjM Software Design.

Minissale, P., \& Spampinato, G. (1985). Osservazioni fitosociologiche sul «Lago Gurrida» (Sicilia nord-orientale). Plant Biosystems, 119(3-4), 197-225. https://doi.org/10.1080/11263508509428015

Mitrakos, K. (1980). A theory for Mediterranean plant life. Acta oecologica. Série Oecologia plantarum Montreuil, 1(3), 245-252.

Mucina, L., Bültman, H., Dierssen, K., Theurillat, J.-P., Dengler, J., Čarni, A., Šumberová, K., Raus, T., Di Pietro, R., Gavilán Garcia, R., Chytrý, M., Iakushenko, D., Schaminée, J.H.J., Bergmeier, E., Santos Guerra, A., Daniëls, F.J.A., Ermakov, N., Valachovič, M., Pigantti, S., Rodwell, J.S., Pallas, J., Capelo, J., Weber, H.E., Lysenko, T., Solomeshch, A., Dimopoulos, P., Aguiar, C., Freitag, H., Hennekens, S.M., \& Tichý, L. (2016). Vegetation of Europe: hierarchical floristic classification system of vascular plant, bryophyte, lichen, and algal communities. Applied Vegetation Science, 19, 3-264. https://doi. org/10.1111/avsc. 12257

Mucina, L., Grabherr, G., \& Ellmauer, T. (1993). Die Pflanzengesellschaften Österreichs. Anthropogene Vegetation. Gustav Fisher Verlag.

Orsenigo, S., Fenu, G., Gargano, D., Montagnani, C., Abeli, T., Alessandrini, A., Bacchetta, G., Bartolucci, F., Carta, A., Castello, M., Cogoni, D., Conti, F., Domina, G., Foggi, B., Gennai, M., Gigante, D., Iberite, M., Peruzzi, L., Pinna, M.S., Prosser, F., Santangelo, A., Selvaggi, A., Stinca, A., Villani, M., Wagensommer, R.P., Tartaglini, N., Duprè, E., Blasi, C., \& Rossi, G. (2020). Red list of threatened vascular plants in Italy. Plant Biosystems, 155(2), 310-335. https://doi. org/10.1080/11263504.2020.1739165

Orsenigo, S., Montagnani, C., Fenu, G., Gargano, D., Peruzzi, L., Abeli, T., Alessandrini, A., Bacchetta, G., Bartolucci, F., Bovio, M., Brullo, C., Brullo, S., Carta, A., Castello, M., Cogoni, D., Conti, F., Domina, G., Foggi, B., Gennai, M., Gigante, D., Iberite, M., Lasen, C., Magrini, S., Perrino, E.V., Prosser, F., Santangelo, A., Selvaggi, A., Stinca, A., Vagge, I., Villani, M., Wagensommer, R.P., Wilhalm, T., Tartaglini, N., Duprè, E., Blasi, C., \& Rossi, G. (2018). Red Listing plants under full national responsibility: Extinction risk and threats in the vascular flora endemic to Italy. Biological Conservation, 224, 213-222. https://doi.org/10.1016/j.biocon.2018.05.030

Orsomando, E. (1985). Alberi arbustie fiori della Valnerina. Edizioni Thyrus, Umbriagraf.

Orsomando, E., \& Catorci, A. (1995). Aspetti floristici e vegetazionali del territorioValnerina-Monti Sibillini. In R. Cordella, \& U. Regoli (Eds.), Valnerina. Ambiente-Aree protette, Economia-Beni culturali. Italia Nostra-Valnerina (pp. 36-52). Edizioni Era Nuova s.r.l.

Orsomando, E., \& Pedrotti, F. (1977). Vegetation in the municipalities of the Umbrian Apennine ridge (Nursino and Eugubino districts). CRURES, Naturalistic and Ecological Research Section. [in Italian] 
Orsomando, E., \& Pedrotti, F. (1982). Les "Marcite" de Norcia. In F. Pedrotti (Ed.), Guide-Itinéraire, ExcursionInternationale de Phytosociologie en Italie centrale (2-11 juillet 1982) (pp. 379-384). Centrostampa Università di Camerino.

Orsomando, E., Ragni, D., \& Segatori, R. (2004). Siti Natura 2000 in Umbria - manuale per la conoscenza e l'uso. Tip. S. Giuseppe s.r.l.

Paolucci, L. (1890). Flora Marchigiana. Premiato Stabilimento TipoLit. Federici.

Pedrotti, F. (1963). Esempio di Arrhenatheretum dell'Appennino Umbro-Marchigiano. Rendiconti Istituto di Scienze Camerino, 4, 210-215.

Pedrotti, F. (1965). Censimento di ambienti umidi meritevoli di protezione: i piani carsici dell'Appennino umbro-marchigiano. Atti Istituto di Botanica Laboratorio Crittogamico Pavia, 1, 141-158.

Pedrotti, F. (1967). Carta fitosociologica della vegetazione dei piani di Montelago. Notiziario Società Italiana di Fitosociologia, 4, 1-8.

Pedrotti, F. (1976). Les prairies permanentes humides de l'Apennin Central: Phytosociologie et Cartographie. Colloques Phytosociologiques, 5, 181-187.

Pedrotti, F. (1982). Carta della vegetazione del Foglio Acquasanta. C.N.R.

Pedrotti, F. (1992). Tipificazione e correzione dell'associazione CariciFraxinetum angustifoliae Pedrotti 1970. Documents Phytosociologiques, 14, 165-166.

Pedrotti, F. (2002). Flora, vegetazione e paesaggio vegetale del Parco nazionale dei Monti Sibillini. Parco Nazionale dei Monti Sibillini. Quaderni scientifici-divulgativi. Parco Monti Sibillini.

Pedrotti, F., \& Cortini Pedrotti, C. (1982). Les "Caricetea" du Pian Perduto de Gualdo. In: F. Pedrotti (Ed.), Guide-Itinéraire Excursion Internationale de Phytosociologie en Italie centrale (Camerino, 2-11 juillet 1982) (pp. 337-340). Università degli Studi, Camerino.

Pesaresi, S., Biondi, E., \& Casavecchia, S. (2017). Bioclimates of Italy. Journal of Maps, 13(2), 955-960. https://doi.org/10.1080/17445647. 2017.1413017

Pignatti, S., Guarino, R., \& La Rosa, M. (2017a). Flora d'Italia. Vol. 1. (2nd ed.). Edagricole.

Pignatti, S., Guarino, R., \& La Rosa, M. (2017b). Flora d'Italia. Vol. 2. (2nd ed.). Edagricole.

Pignatti, S., Guarino, R., \& La Rosa, M. (2017c). Flora d'Italia. Vol. 3. (2nd ed.). Edagricole.

Pignatti, S., Guarino, R., \& La Rosa, M. (2017d). Flora d'Italia. Vol. 4. (2nd ed.). Edagricole.

Pignatti, S., Menegoni, P., \& Pietrosanti, S. (2005). Bioindicazione attraverso le piante vascolari. Valori di indicazione secondo Ellenberg (Zeigerwerte) per le specie della Flora d'Italia. Braun-Blanquetia, 39, 1-97.

Pirone, G. (1997). Il paesaggio vegetale di Rivisondoli, aspetti della flora e della vegetazione. Azienda Autonoma di Soggiorno e Turismo Rivisondoli (AQ).

Pirone, G. (2000). La vegetazione ripariale nei versanti nord-orientali del Gran Sasso d'Italia e dei Monti della Laga. Fitosociologia, 37(2), 65-86.
Pirone, G., Ciaschetti, G., \& Frattaroli, A. R. (2004). La vegetazione del bosco di S. Antonio (Pescocostanzo, Abruzzo). Micologia e Vegetazione Mediterranea, 19(2), 163-176.

Poldini, L., \& Sburlino, G. (2005). Terminologia fitosociologica essenziale. Fitosociologia, 42(1), 57-69.

Regione Marche. (2014). Decree of the President of the Council of the Marche Region, DPGR n. 95, 23/04/2014. L.R. 52/74, art. 7 - "Aree Floristiche protette": riperimetrazione delle aree e aggiornamento dell'elenco delle specie. http://www.ambiente.regione.marche.it/Portals/0/ Ambiente/Natura/InfrastrutturaVerde/Decreto_n95_2014.pdf

Rossi, G., Montagnani, C., Gargano, D., Peruzzi, L., Abeli, T., Ravera, S., Cogoni, A., Fenu, G., Magrini, S., Gennai, M., Foggi, B., Wagensommer, R. P., Venturella, G., Blasi, C., Raimondo, F. M., \& Orsenigo, S. (2013). Lista rossa della Flora italiana. 1. Policy species e altre specie minacciate. Comitato Italiano IUCN, Ministero Ambiente e Tutela Territorio e Mare.

Sanguinetti, P. (1852-1868). Florae Romanae prodromus alter: exhibens plantas vasculares circa Romam in Cisapenninis pontificiae dictionis provinciis in Umbria et Piceno sponte venientes: secundum sexuale systema dispositas. Ex Typographeo Bonarum Artium.

Schaffers, A. P., \& Sýkora, K. V. (2000). Reliability of Ellenberg indicator values for moisture, nitrogen and soil reaction: A comparison with field measurements. Journal of Vegetation Science, 11, 225-244. https://doi.org/10.2307/3236802

Sebastià, M.T., De Bello, F., Puig, L., \& Taull, M. (2008). Grazing as a factor structuring grasslands in the Pyrenees. Applied Vegetation Science, 11, 215-222. https://doi.org/10.3170/2008-7-18358

Servilli, S., \& Dell'Orso, M. (2000). Le orchidee dei Monti Sibillini. GIROS Notizie, 15, 14-15.

Tammaro, F. (1986). Un esempio di cartografia floristica in Basilicata: la distribuzione del genere Verbascum L. (Scrophulariaceae).

Biogeographia-The Journal of Integrative Biogeography, 10(1), 237-246. https://doi.org/10.21426/B610110301

Tardella, F. M., \& Di Agostino, V. M. (2020). Vegetation of the Altipiani di Colfiorito" wetlands (central Apennines, Italy). Plant Sociology, 57(2), 133-132. https://doi.org/10.3897/pls2020572/04

Tardella, F. M., Ballelli, S., Raponi, M., Piccioni, S., \& Orsomando, E. (2002). Aspetti floristici e vegetazionali del Piano di Ricciano (Umbria). Plestia Colfiorito, 25, 69-85.

Tomasi, D., \& Caniglia, G. (2004). La vegetazione de le Poscole: importante sito di biodiversità in Provincia di Vicenza (N-E Italia). Lavori Società Veneta di Scienze Naturali, 29, 71-78.

Tondi, G. (2000). La flora di altitudine dei Monti della Laga (Appennino centrale). Annali Museo Civico Rovereto Sezione: Archeologia, Storia, Scienze Naturali, Suppl 14, 177-190.

Ubaldi, D., Zanotti, A. L., Puppi, G., Speranza, M., \& Corbetta, F. (1987). Sintassonomia dei boschi caducifogli mesofili dell'Italia peninsulare. Notiziario della Società Italiana di Fitosociologia, 23: 31-62.

Venanzoni, R. (1992). I prati umidi e inondati dell'Alta Valle del Velino (Rieti-Italia Centrale). Documents Phytosociologiques, 14 149-164.

Venanzoni, R., \& Gigante, D. (2000). Contributo alla conoscenza della vegetazione degli ambienti umidi dell'Umbria. Fitosociologia, $37(2), 13-63$. 
Wamelink, G. W. W., Joosten, V., Van Dobben, H. F., \& Berendse, F. (2002). Validity of Ellenberg indicator values judged from physicochemical field measurements. Journal of Vegetation Science, 13(2), 269-278. https://doi.org/10.1111/j.1654-1103.2002.tb02047.x

Warren, R. J. (2008). Mechanisms driving understory evergreen herb distributions across slope aspects: as derived from landscape position. Plant Ecology, 198(2), 297-308. https://doi.org/10.1007/s11258-0089406-1

Zelený, D., \& Schaffers, A. P. (2012). Too good to be true: pitfalls of using mean Ellenberg indicator values in vegetation analyses. Journal of Vegetation Science, 23(3), 419-431. https://doi.org/10.1111/j.16541103.2011.01366.x

\section{Appendix 1: Locality and data for each relevé}

\section{Table 1}

Rel.1-2: Sommità Monte Oialona (AP), 25/05/2015; Rel. 3-4: Sommità dei prati di Santa Maria in Pantano (AP), 25/05/2015; Rel.5-7: Monte Ceresa (AP), 21/07/2015; Rel. 8-10: Passo Galluccio (AP), 28/05/2015; Rel.11-12: Santa Maria in Pantano (AP), 29/06/2015; Rel.13: Santa Maria in Pantano (AP), 01/07/2015.

\section{Table 3}

Rel.1-2: San Pietro d'Arli - Piana della Forcella (AP), 21/07/2015; Rel.3: Ponte d'Arli (AP), 21/07/2015; Rel.4: San Pietro d'Arli - Piana della Forcella (AP), 21/07/2015; Rel.5-7: Montemonaco (AP), 04/07/2015; Rel.8-9: Rascio di Montemonaco (AP), 04/07/2015; Rel.10-11: Montemonaco (AP), 04/07/2015; Rel.1213: Bivio Monte Sibilla-Fraz. Collina (AP), 28/05/2015; Rel.14: Montemonaco, strada per Cese, 04/07/2015; Rel. 15: Colle Propezzano, 04/07/2015, Rel.16: Montemonaco (AP), 06/06/2015; Rel. 17: Santa Maria in Pantano, 04/07/2015; Rel.18: Pretattoni, vicino strada per Montefortino (FM), 28/05/2015; Rel.19: Montemonaco per Vallefiume (AP), 28/05/2015.

\section{Table 4}

Rel.1: Santa Maria in Pantano (AP), 29/06/2015; Rel.23: Santa Maria in Pantano (AP), 01/07/2015; Rel.4-7: Santa Maria in Pantano (AP), 29/06/2015; Rel.8-11: Santa Maria in Pantano (AP), 01/07/2015; Rel.12-14: Balzo di Montegallo (AP), 24/05/2015; Rel.15-21: Abetito-frazione di Montegallo (AP), 24/05/2015; Rel.22-23. Balzo di Montegallo (AP), 24/05/2015.

\section{Supplementary material on-line}

Table S1 - List of taxa of conservation interest in the study area.

Table S2 - Chorological spectrum of taxa at the species and subspecies level found in the study area.

Table S3 - Descriptive statistics.

Table S4 - List of constant species associated to each cluster of Figure 2.

Table S5 - List of the diagnostic species resulting from Indicator species analysis associated to each cluster of Figure 2. 
Table 1: Dwarf shrub and herbaceous communities of the Calluno-Ulicetea and Nardetea strictae classes.

Tabela 1: Grmiščne in zeliščne združbe razredov Calluno-Ulicetea in Nardetea strictae.

\begin{tabular}{|c|c|c|c|c|c|c|c|c|c|c|c|c|c|c|c|}
\hline Relevé number & 1 & 2 & 3 & 4 & 5 & 6 & 7 & 8 & 9 & 10 & 11 & 12 & 13 & \multirow{7}{*}{$\begin{array}{l}\text { Uू } \\
\text { : } \\
\text { : } \\
\bar{U} \\
0\end{array}$} & \\
\hline Relevé number in Figure 2 & 2 & 3 & 4 & 5 & 44 & 42 & 43 & 53 & 54 & 55 & 11 & 12 & 19 & & \\
\hline Altitude (m a.s.l) & 1120 & 1125 & 1127 & 1130 & 1375 & 1380 & 1380 & 1275 & 1195 & 1205 & 1210 & 1220 & 1180 & & \\
\hline Aspect & 0 & 0 & 45 & 45 & 90 & 180 & 180 & 135 & 135 & 135 & 112,5 & 180 & 0 & & \\
\hline Slope $\left({ }^{\circ}\right)$ & 1 & 1 & 5 & 5 & 35 & 25 & 1 & 10 & 25 & 25 & 5 & 22,5 & 5 & & \\
\hline Surface (mq) & 3 & 4 & 20 & 20 & 70 & 100 & 100 & 100 & 100 & 100 & 100 & 100 & 30 & & \\
\hline Coverage $(\%)$ & 100 & 100 & 98 & 98 & 100 & 100 & 100 & 100 & 100 & 100 & 100 & 100 & 100 & & \\
\hline
\end{tabular}

\section{Calluna vulgaris community and higher syntaxa}

Calluna vulgaris

Vaccinium myrtillus

Erica scoparia subsp. scoparia

$\begin{array}{llll}3 & 4 & 4 & 4 \\ 1 & 1 & + & + \\ 2 & . & 1 & .\end{array}$

Char. species of the Campanulo micranthae-Nardetum strictae ass. and nardetosum strictae subass.

Nardus stricta

Luzula multiflora subsp. multiflora

Agrostis capillaris subsp. capillaris

Cynosurus cristatus

Campanula micrantha

Silene ciliata subsp. graefferi

Species of Ranunculo pollinensis-Nardion strictae all.

Potentilla rigoana

Ranunculus pollinensis

Ranunculus apenninus

Species of Nardetalia strictae ord. and Nardetea strictae class

Genista sagittalis

Festuca rubra group

Danthonia decumbens subsp. decumbens

Potentilla erecta

Polygala vulgaris

Viola canina

Rumex nebroides

Dianthus hyssopifolius

Avenella flexuosa subsp. flexuosa

Bellardiochloa variegata subsp. variegata

Carex pallescens

Luzula campestris subsp. campestris

Coeloglossum viride

Veronica officinalis

Poa alpina subsp. alpina

Species of Festuco-Brometea class

Brachypodium rupestre

Helianthemum nummularium subsp. obscurum

Trifolium montanum subsp. rupestre

Bromopsis erecta subsp. erecta

Carex caryophyllea

Thesium linophyllon

Cerastium arvense subsp. suffruticosum

Briza media

Scabiosa columbaria

Knautia calycina

Campanula glomerata 


\begin{tabular}{lllllllllllllll}
\hline Relevé number & 1 & 2 & 3 & 4 & 5 & 6 & 7 & 8 & 9 & 10 & 11 & 12 & 13
\end{tabular}

Galium verum

Phyteuma orbiculare

Thymus moesiacus

Ranunculus polyanthemophyllus

Linum catharticum subsp. catharticum

Viola eugeniae

Ornithogalum comosum

Centaurea jacea subsp. gaudinii

Podospermum purpureum

Festuca circummediterranea

Senecio scopolii subsp. floccosus

Hippocrepis comosa subsp. comosa

Anacamptis morio

Centaurea triumfettii

Dianthus carthusianorum

Muscari neglectum

Poterium sanguisorba subsp. balearicum

Thymus longicaulis subsp. longicaulis

Saxifraga bulbifera

Festuca inops

Astragalus danicus

Trifolium ochroleucon

Dactylorhiza sambucina

Eryngium amethystinum

Koeleria splendens

Carlina acanthifolia

Crocus neglectus

Pentanema hirtum

Allium sphaerocephalon

Bupleurum falcatum subsp. cernuum

Carex flacca subsp. erythrostachys

Euphrasia stricta

Filipendula vulgaris

Gentiana verna

Ononis spinosa

Salvia pratensis

Neotinea ustulata

Neottia ovata

Prunella laciniata

Anthillis vulneraria subsp.rubriflora

Ingr. species from Molinio-Arrhenatheretea class

Leontodon hispidus

Dactylis glomerata subsp. glomerata

Anthoxanthum odoratum

Trifolium pratense subsp. pratense

Tragopogon pratensis

Holcus lanatus subsp. lanatus

Rumex acetosa subsp. acetosa

Lotus corniculatus

Plantago lanceolata

Gymnadenia conopsea

Ranunculus acris 


\begin{tabular}{|c|c|c|c|c|c|c|c|c|c|c|c|c|c|c|c|}
\hline Relevé number & 1 & 2 & 3 & 4 & 5 & 6 & 7 & 8 & 9 & 10 & 11 & 12 & 13 & & \\
\hline Narcissus poëticus & . & . & . & . & . & . & . & + & + & + & + & . & . & 4 & 30,8 \\
\hline Rhinanthus alectorolophus & . & . & . & . & . & . & . & 2 & . & . & . & 1 & 1 & 3 & 23,1 \\
\hline Carex distans & . & . & . & . & . & . & . & . & . & . & + & + & . & 2 & 15,4 \\
\hline Cerastium holosteoides & . & . & . & . & . & . & . & . & + & + & . & . & . & 2 & 15,4 \\
\hline Plantago media & . & . & . & . & . & + & . & . & . & + & . & . & . & 2 & 15,4 \\
\hline Carex hirta & . & . & . & . & . & . & . & . & . & . & 1 & . & . & 1 & 7,7 \\
\hline Centaurea nigrescens & . & . & . & . & . & . & . & . & . & . & . & 1 & . & 1 & 7,7 \\
\hline Lathyrus pratensis & . & . & . & . & . & . & . & . & . & . & 1 & . & . & 1 & 7,7 \\
\hline Primula veris subsp. columnae & . & . & . & . & . & . & . & 1 & . & . & . & . & . & 1 & 7,7 \\
\hline Rhinanthus minor & . & . & . & . & . & . & . & . & . & . & . & . & 1 & 1 & 7,7 \\
\hline Achillea millefolium & . & . & . & . & . & + & . & . & . & . & . & . & . & 1 & 7,7 \\
\hline Colchicum lusitanum & . & . & . & . & . & . & . & . & . & . & . & + & . & 1 & 7,7 \\
\hline Daucus carota & . & . & . & . & . & . & . & . & . & . & . & + & . & 1 & 7,7 \\
\hline Leucanthemum vulgare subsp. vulgare & . & . & . & . & . & . & . & . & . & . & . & + & . & 1 & 7,7 \\
\hline Lolium arundinaceum subsp. arundinaceum & . & . & . & . & . & . & . & . & . & . & + & . & . & 1 & 7,7 \\
\hline Lychnis flos-cuculi subsp. flos-cuculi & . & . & . & . & . & . & . & . & . & . & + & . & . & 1 & 7,7 \\
\hline Onobrychis viciifolia & . & . & . & . & . & . & . & . & . & + & . & . & . & 1 & 7,7 \\
\hline Pedicularis hoermanniana & . & . & . & . & . & . & . & + & . & . & . & . & . & 1 & 7,7 \\
\hline Poa trivialis & . & . & . & . & . & . & . & . & . & . & + & . & . & 1 & 7,7 \\
\hline Trifolium dubium & . & . & . & . & . & . & . & . & . & . & + & . & . & 1 & 7,7 \\
\hline \multicolumn{16}{|l|}{ Ingr. species from Elyno-Seslerietea class } \\
\hline Galium anisophyllon & . & . & . & . & . & . & . & 1 & + & + & + & 1 & + & 6 & 46,2 \\
\hline Carlina acaulis subsp. caulescens & . & . & . & . & + & + & + & + & + & + & . & . & . & 6 & 46,2 \\
\hline Helictochloa praetutiana subsp. praetutiana & . & . & . & . & . & . & . & 1 & 1 & 1 & + & + & . & 5 & 38,5 \\
\hline Senecio apenninus & . & . & . & . & . & + & + & 2 & 1 & . & . & . & . & 4 & 30,8 \\
\hline Carex macrolepis & . & . & . & . & . & . & . & + & . & . & . & . & . & 1 & 7,7 \\
\hline Gentiana utriculosa & . & . & . & . & . & . & . & + & . & . & . & . & . & 1 & 7,7 \\
\hline Gentiana lutea & . & . & . & . & . & . & . & $\mathrm{r}$ & . & . & . & . & . & 1 & 7,7 \\
\hline \multicolumn{16}{|l|}{ Companion species } \\
\hline Cruciata glabra & . & . & . & . & 1 & 1 & 1 & 1 & 1 & 1 & + & + & 1 & 9 & 69,2 \\
\hline Alchemilla sp. & . & . & . & . & . & + & + & 1 & + & + & 1 & . & + & 7 & 53,8 \\
\hline Trifolium alpestre & . & . & . & . & + & 1 & 1 & 1 & + & . & . & + & . & 6 & 46,2 \\
\hline Betonica officinalis & . & . & . & . & + & . & . & $\mathrm{r}$ & $\mathrm{r}$ & + & . & + & + & 6 & 46,2 \\
\hline Asphodelus macrocarpus subsp. macrocarpus & . & . & . & . & 2 & 3 & 3 & . & + & . & + & . & . & 5 & 38,5 \\
\hline Genista tinctoria & . & . & . & . & . & + & . & + & . & . & 1 & 2 & 1 & 5 & 38,5 \\
\hline Veronica chamaedrys & . & . & . & . & + & + & + & + & + & . & . & . & . & 5 & 38,5 \\
\hline Campanula rapunculus & . & . & . & . & . & . & . & + & + & + & . & + & + & 5 & 38,5 \\
\hline Oreoselinum nigrum & . & + & . & . & . & . & . & 3 & + & . & + & . & . & 4 & 30,8 \\
\hline Grafia golaka & + & + & . & . & . & $\cdot$ & . & . & . & . & + & . & 2 & 4 & 30,8 \\
\hline Arabis hirsuta & . & . & . & . & . & + & + & + & . & + & . & . & . & 4 & 30,8 \\
\hline Scorzoneroides cichoriacea & . & . & . & . & . & . & . & + & + & + & . & . & + & 4 & 30,8 \\
\hline Pilosella officinarum & . & . & . & . & . & . & . & . & $\mathrm{r}$ & + & . & + & + & 4 & 30,8 \\
\hline Silene nutans & . & . & . & . & . & . & . & $\mathrm{r}$ & + & 1 & . & . & . & 3 & 23,1 \\
\hline Ajuga reptans & . & . & . & . & . & $\cdot$ & . & + & + & + & . & . & . & 3 & 23,1 \\
\hline Silene italica & . & . & . & . & + & + & + & . & . & . & . & . & . & 3 & 23,1 \\
\hline Galium mollugo & . & . & . & . & + & + & . & . & $\mathrm{r}$ & . & . & . & . & 3 & 23,1 \\
\hline Laserpitium latifolium & . & . & . & . & . & . & . & $\mathrm{r}$ & . & . & + & + & . & 3 & 23,1 \\
\hline Bistorta vivipara & . & . & . & . & . & + & + & . & . & . & . & . & . & 2 & 15,4 \\
\hline Cirsium lobelii & . & . & . & . & + & $\cdot$ & + & . & . & . & . & . & . & 2 & 15,4 \\
\hline Dichoropetalum carvifolium-chabraei & . & . & . & . & + & + & . & . & . & . & . & . & . & 2 & 15,4 \\
\hline Malva alcea & . & . & . & . & . & + & + & . & . & . & . & . & . & 2 & 15,4 \\
\hline Populus tremula & + & + & . & . & . & . & . & . & . & . & . & . & . & 2 & 15,4 \\
\hline
\end{tabular}




\begin{tabular}{|c|c|c|c|c|c|c|c|c|c|c|c|c|c|c|c|}
\hline Relevé number & 1 & 2 & 3 & 4 & 5 & 6 & 7 & 8 & 9 & 10 & 11 & 12 & 13 & & \\
\hline Pteridium aquilinum subsp. aquilinum & . & . & . & + & . & . & . & . & + & . & . & . & . & 2 & 15,4 \\
\hline Fagus sylvatica subsp. sylvatica & . & . & r & + & . & . & . & . & . & . & . & . & . & 2 & 15,4 \\
\hline Myosotis graui & . & . & . & . & . & . & . & . & $\mathrm{r}$ & + & . & . & . & 2 & 15,4 \\
\hline Platanthera bifolia & . & . & . & . & . & . & . & . & . & . & r & . & + & 2 & 15,4 \\
\hline Thalictrum aquilegiifolium subsp. aquilegiifolium & . & . & . & . & + & . & . & $\mathrm{r}$ & . & . & . & . & . & 2 & 15,4 \\
\hline Potentilla pedata & $\mathrm{r}$ & . & . & r & . & . & . & . & . & . & . & . & . & 2 & 15,4 \\
\hline Cytisus hirsutus & . & . & + & + & . & . & . & . & . & . & . & . & . & 2 & 15,4 \\
\hline Cephalanthera longifolia & . & . & . & . & . & . & . & 1 & . & . & . & . & . & 1 & 7,7 \\
\hline Anemonoides ranunculoides & . & . & . & . & . & . & . & . & . & + & . & . & . & 1 & 7,7 \\
\hline Castanea sativa & . & . & . & + & . & . & . & . & . & . & . & . & . & 1 & 7,7 \\
\hline Dactylorhiza maculata subsp. fuchsii & . & . & . & . & . & . & . & + & . & . & . & . & . & 1 & 7,7 \\
\hline Fragaria vesca subsp. vesca & . & . & . & . & . & . & + & . & . & . & . & . & . & 1 & 7,7 \\
\hline Geranium sanguineum & . & . & . & . & + & . & . & . & . & . & . & . & . & 1 & 7,7 \\
\hline Geum urbanum & . & . & . & . & + & . & . & . & . & . & . & . & . & 1 & 7,7 \\
\hline Juniperus communis & . & . & + & . & . & . & . & . & . & . & . & . & . & 1 & 7,7 \\
\hline Pyrus communis subsp. pyraster & . & . & . & + & . & . & . & . & . & . & . & . & . & 1 & 7,7 \\
\hline Quercus pubescens & . & . & . & + & . & . & . & . & . & . & . & . & . & 1 & 7,7 \\
\hline Rosa arvensis & . & . & . & . & + & . & . & . & . & . & . & . & . & 1 & 7,7 \\
\hline Vicia cracca & . & . & . & . & . & . & . & . & . & . & + & . & . & 1 & 7,7 \\
\hline Vicia sativa & . & . & . & . & . & . & . & . & + & . & . & . & . & 1 & 7,7 \\
\hline Malva moschata & . & . & . & . & . & . & . & $\mathrm{r}$ & . & . & . & . & . & 1 & 7,7 \\
\hline Orobanche gracilis & . & . & . & . & . & . & . & . & . & . & r & . & . & 1 & 7,7 \\
\hline Trifolium scabrum & . &. & . & . & . & . & . & . & + & . & . & . & . & 1 & 7,7 \\
\hline
\end{tabular}

Table 2: Percent cover values of species grouped in phytosociological classes inside relevés clusters and sub-clusters highlighted by cluster analysis. Cluster/sub-cluster IDs refer to Figure 2.

Tabela 2: Pokrovnost v odstotkih vrst združenih po fitocenoloških razredih v klastrih in podklastrih. Klastri in podklastri so enaki kot prikazani v sliki 2 .

$\begin{array}{ccccccc}\text { Cluster / sub-cluster ID } & \text { FB-FO-ES } & \text { MA } & \text { NS } & \text { CU } & \text { LS-ST-H-OR-SS } & \text { Companion species } \\ \text { A } & 32,0 & 18,8 & 28,3 & 10,3 & 0,3 & 10,3 \\ \text { A1 } & 0,3 & 0,0 & 8,4 & 87,5 & 1,4 & 2,4 \\ \text { A2 } & 36,2 & 21,3 & 30,9 & 0,0 & 0,1 & 11,3 \\ \text { B } & 50,5 & 6,6 & 0,0 & 0,0 & 33,1 & 9,7 \\ \text { B1 } & 41,1 & 6,6 & 0,0 & 0,0 & 36,5 & 15,1 \\ \text { B2 } & 49,1 & 4,5 & 0,0 & 0,0 & 37,7 & 8,7 \\ \text { B3 } & 56,7 & 8,2 & 0,0 & 0,0 & 27,5 & 7,5 \\ \text { C } & 14,2 & 72,4 & 0,9 & 0,0 & 2,7 & 9,8 \\ \text { C1 } & 0,3 & 95,1 & 2,7 & 0,0 & 0,9 & 1,0 \\ \text { C2 } & 25,1 & 67,3 & 1,5 & 0,0 & 2,6 & 3,2 \\ \text { C3 } & 7,4 & 72,2 & 0,0 & 0,0 & 3,5\end{array}$

CU - Calluno-Ulicetea; ES - Elyno-Seslerietea; FB - Festuco-Brometea; FO - Festuco hystricis-Ononidetea striatae; H - Helianthemetea guttati; LS - Lygeo sparti-Stipetea tenacissimae; MA - Molino-Arrhenatheretea; NS - Nardetea strictae; OR - Ononido-Rosmarinetea, SS - Sedo-Scleranthetea; ST - Stipo-Trachynietea. 


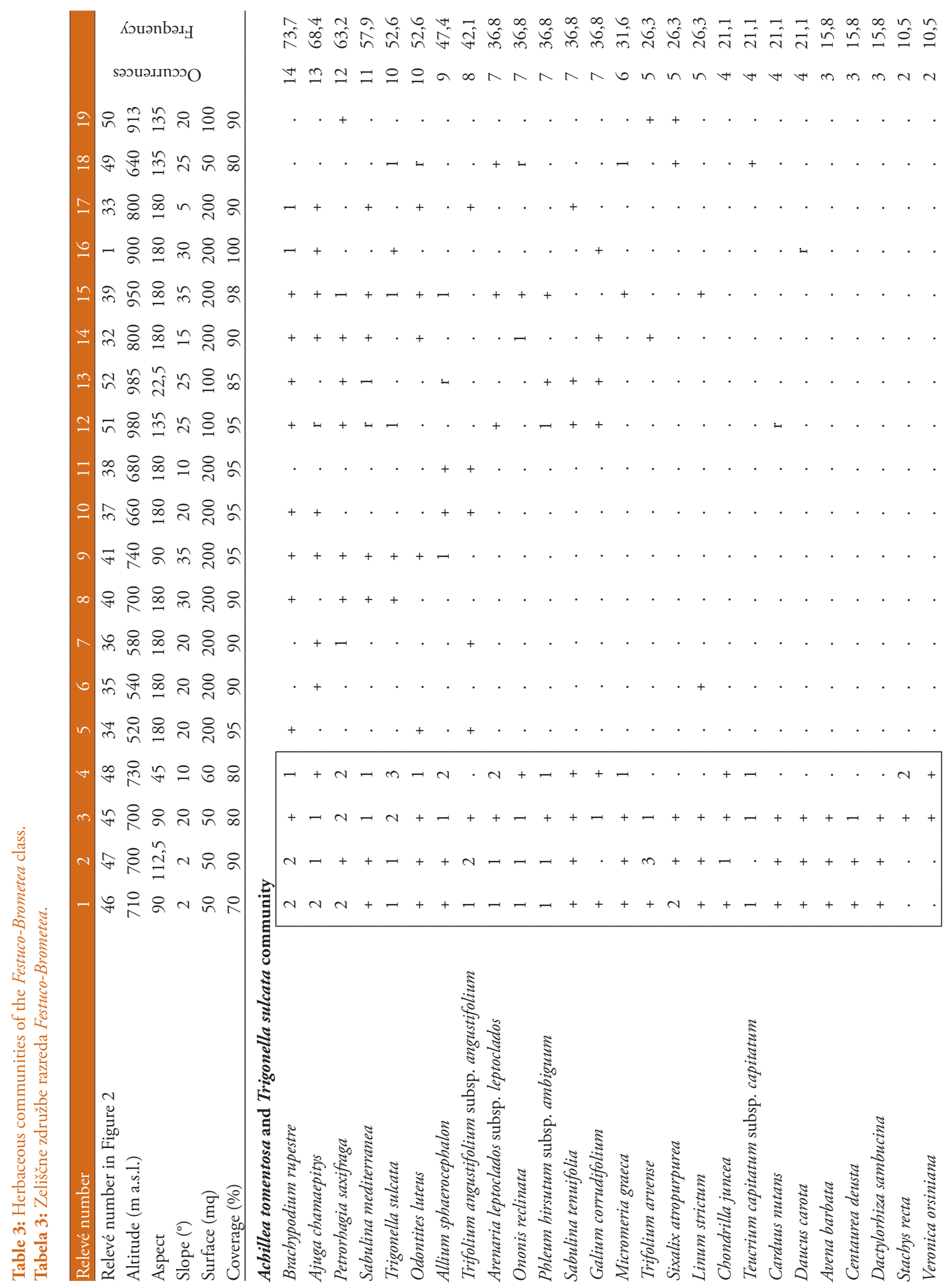




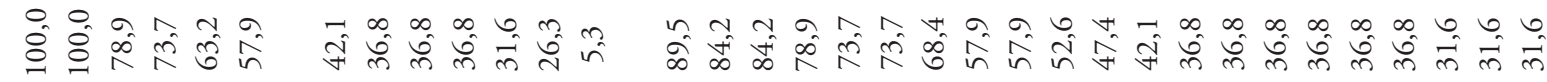

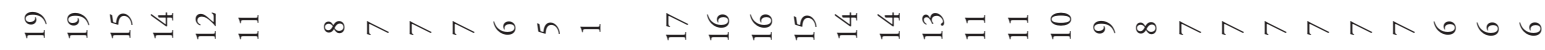

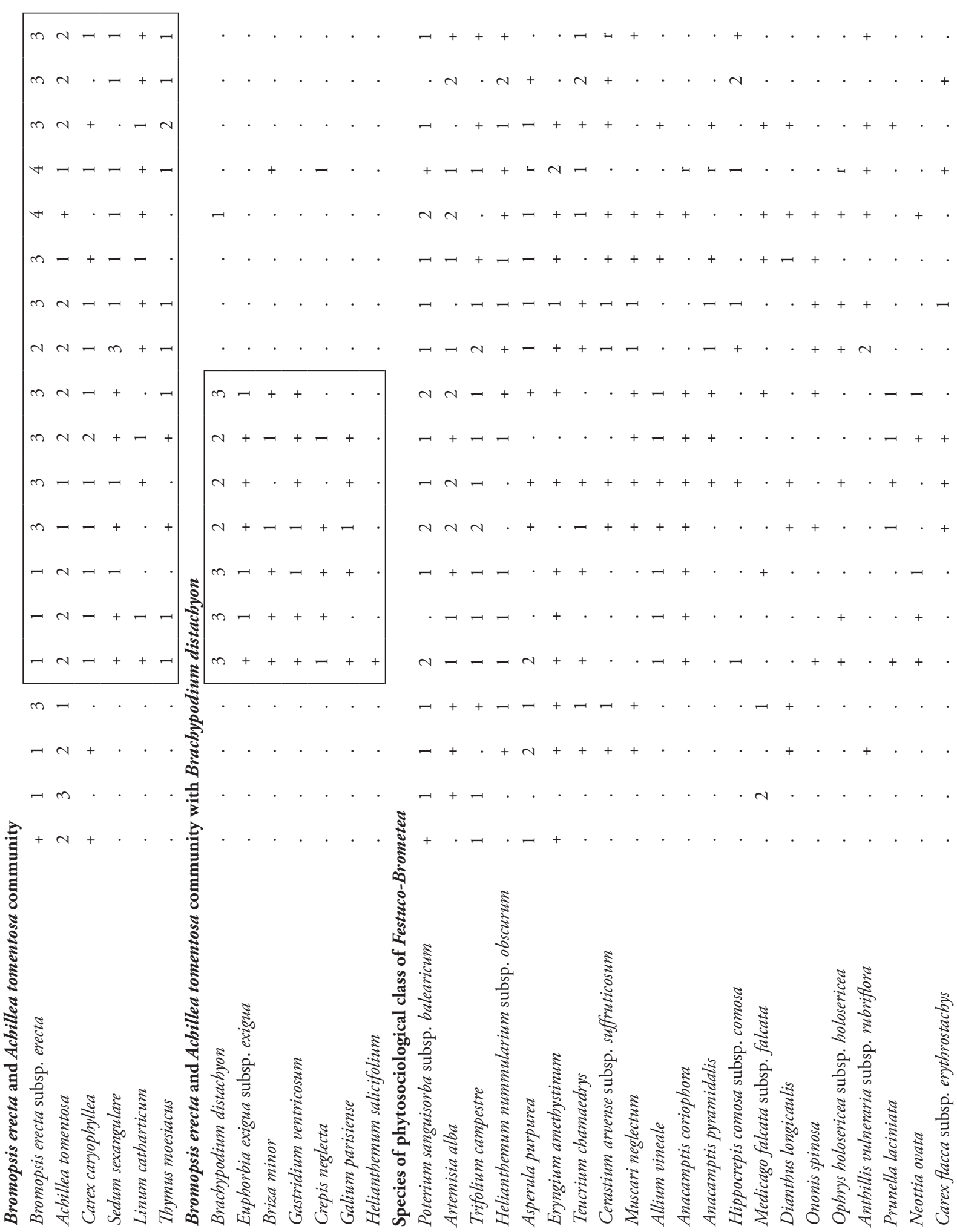




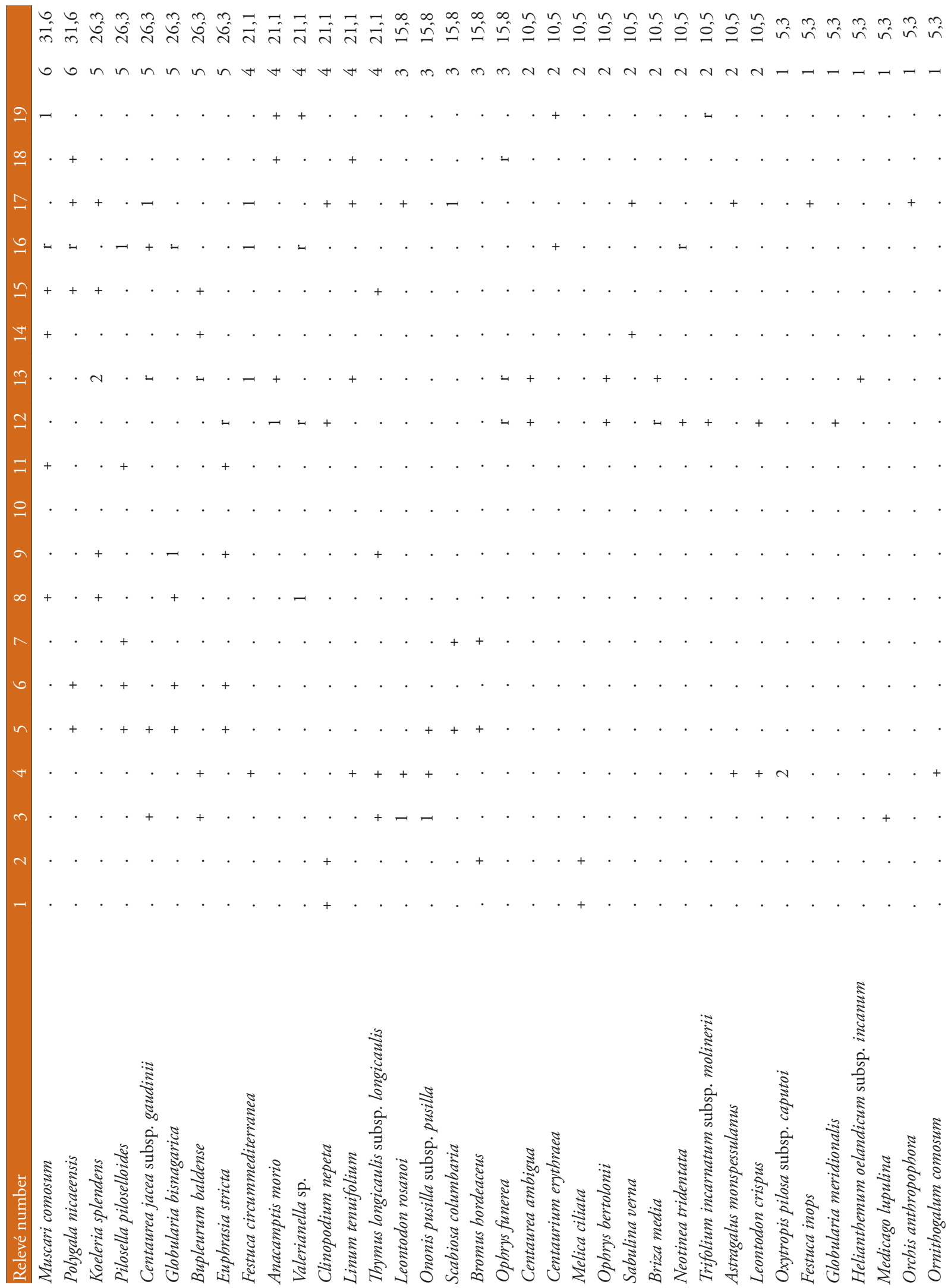




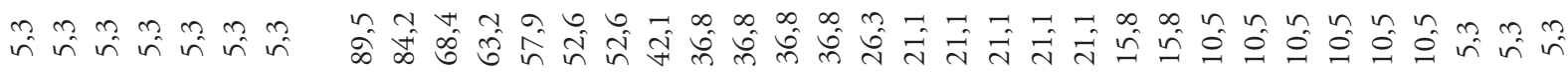

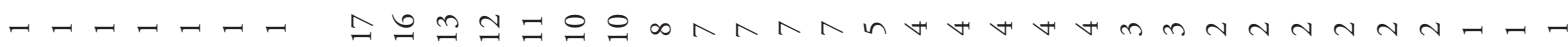

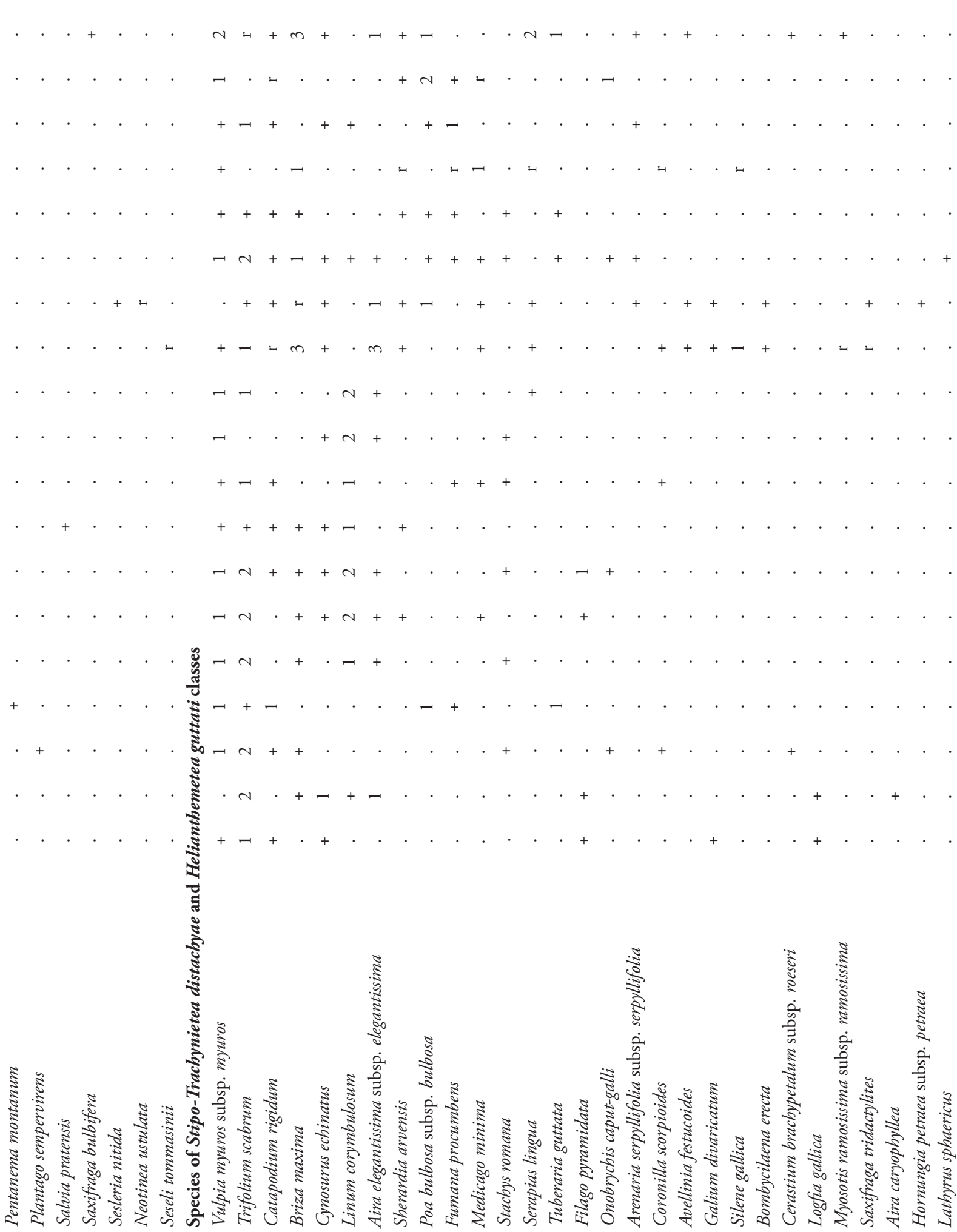




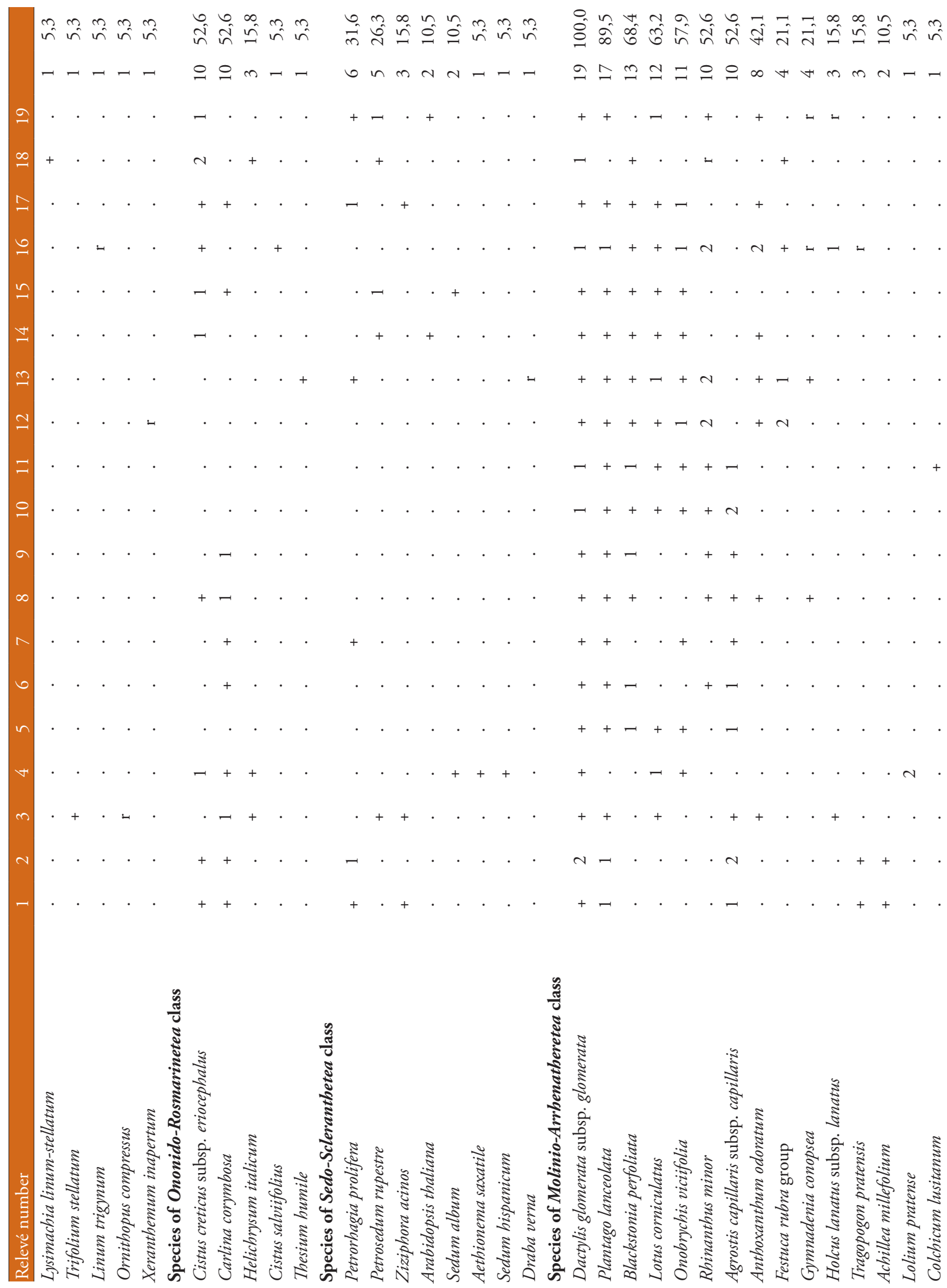




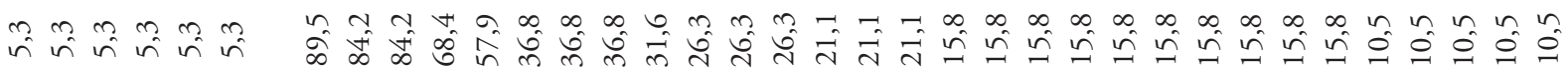

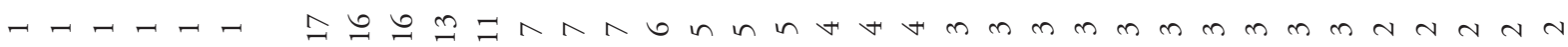

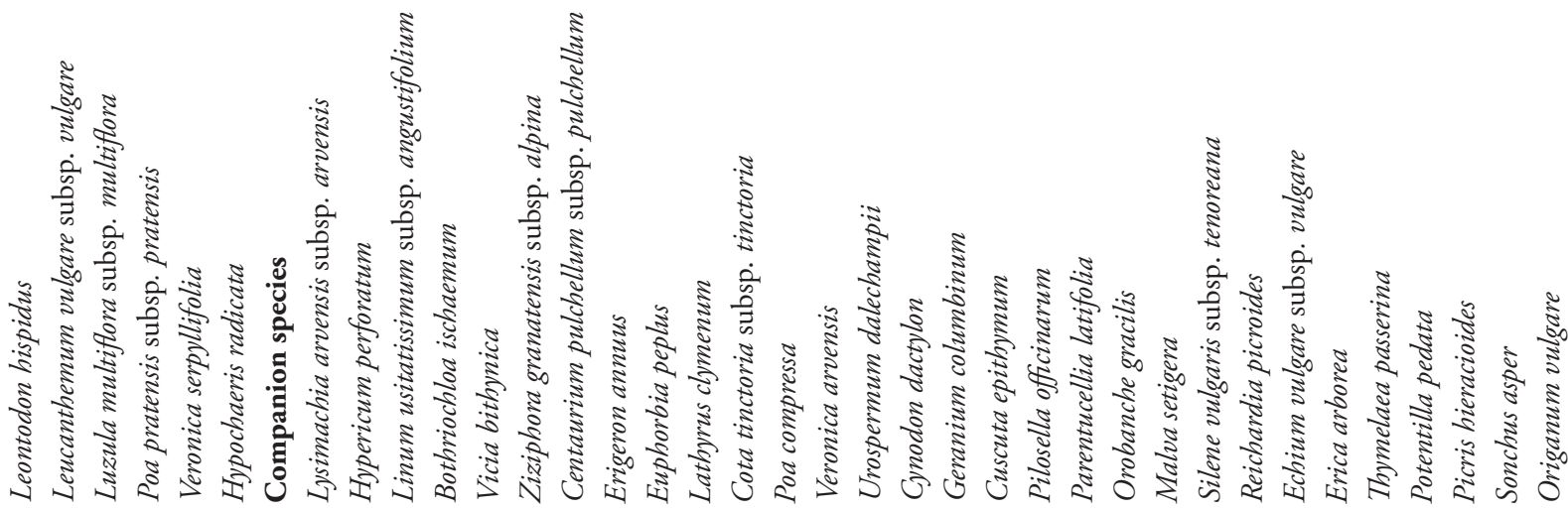




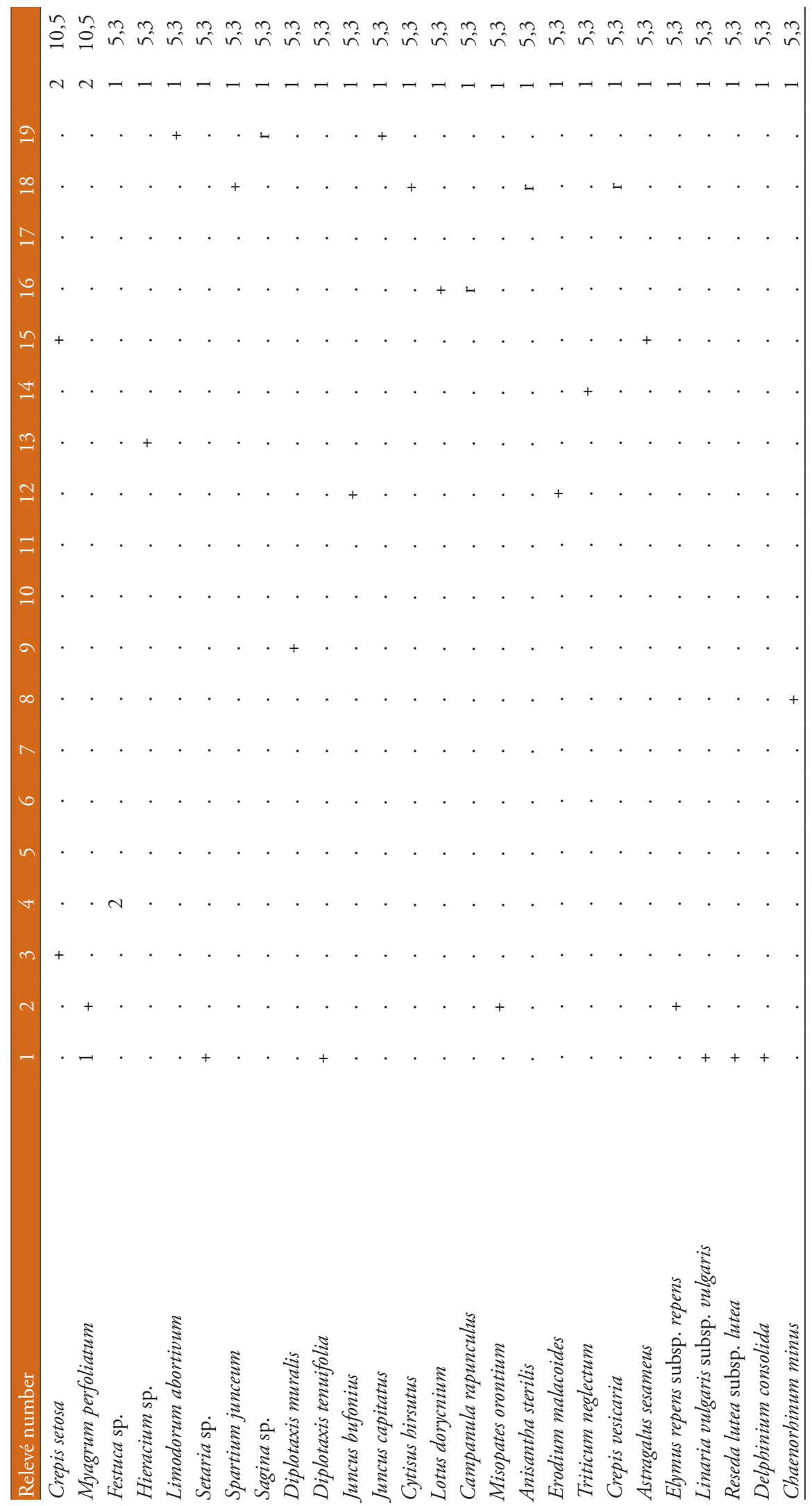




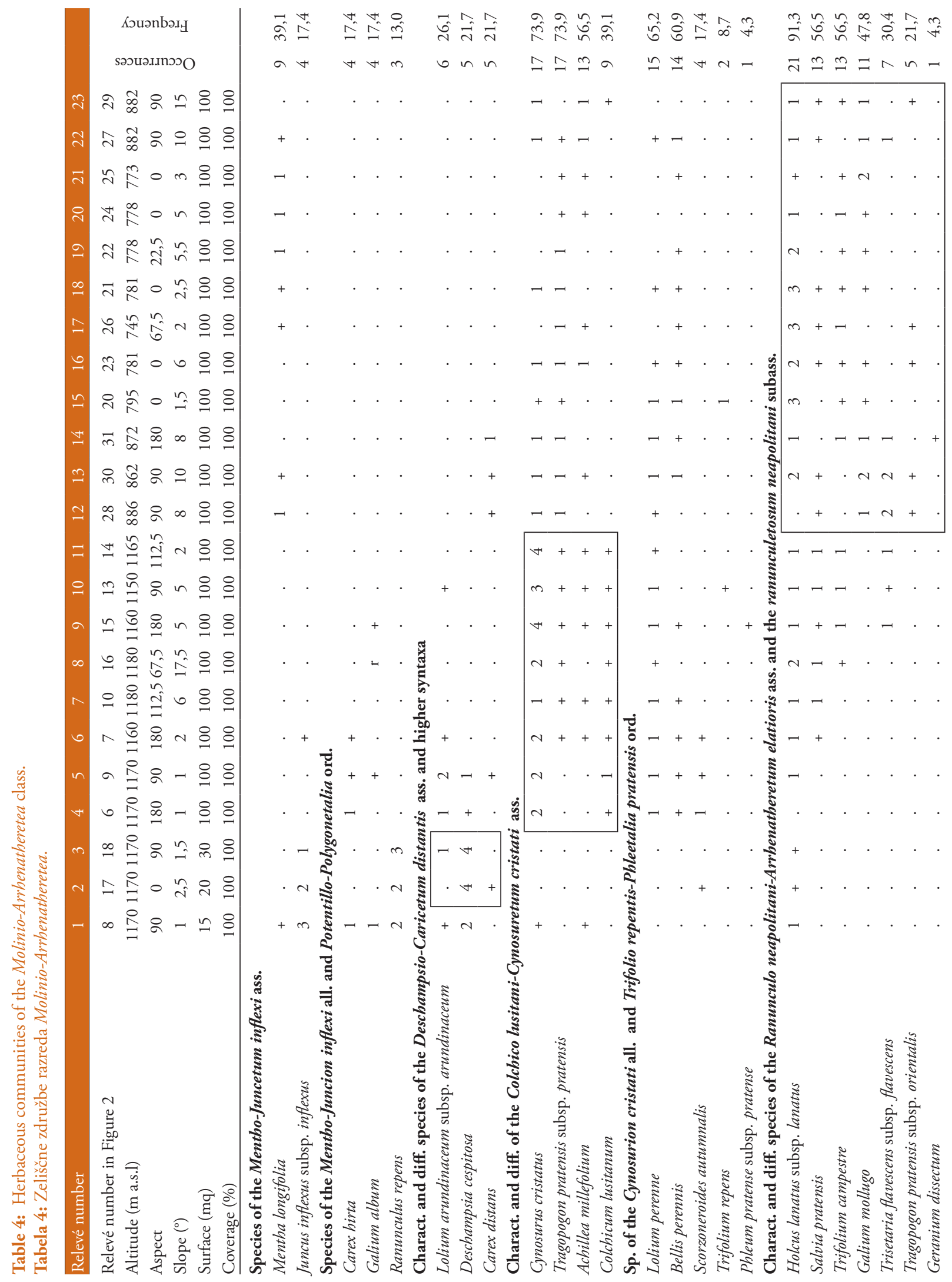




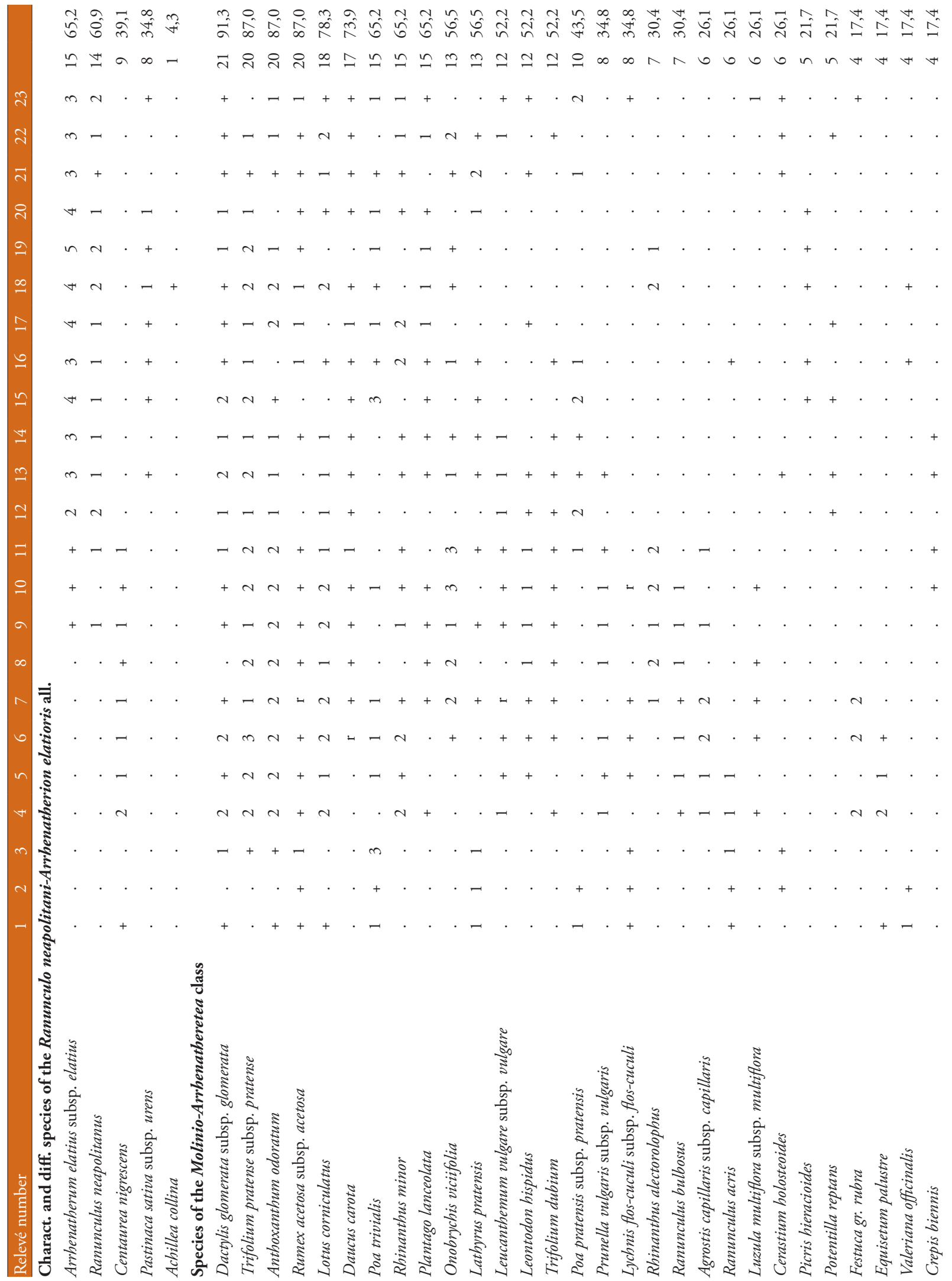




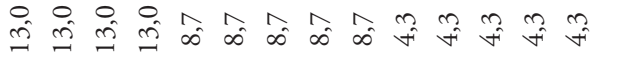
$m m \infty n \sim N-\cdots$
बें ठิ $\because \pm n=0$

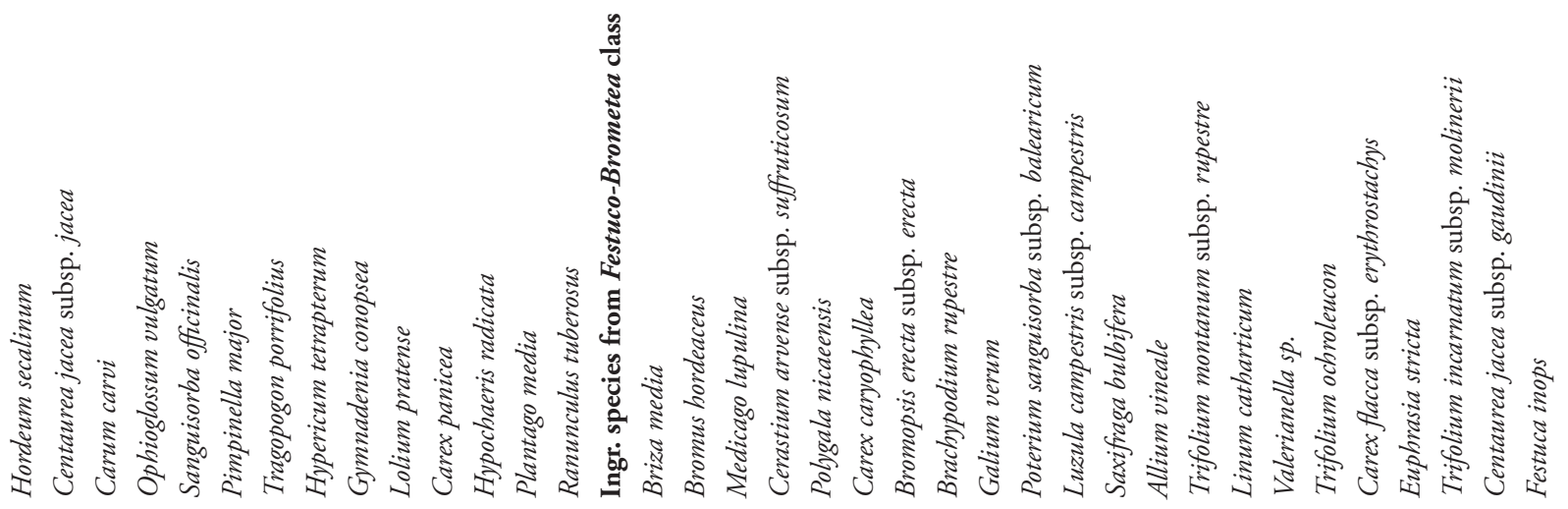




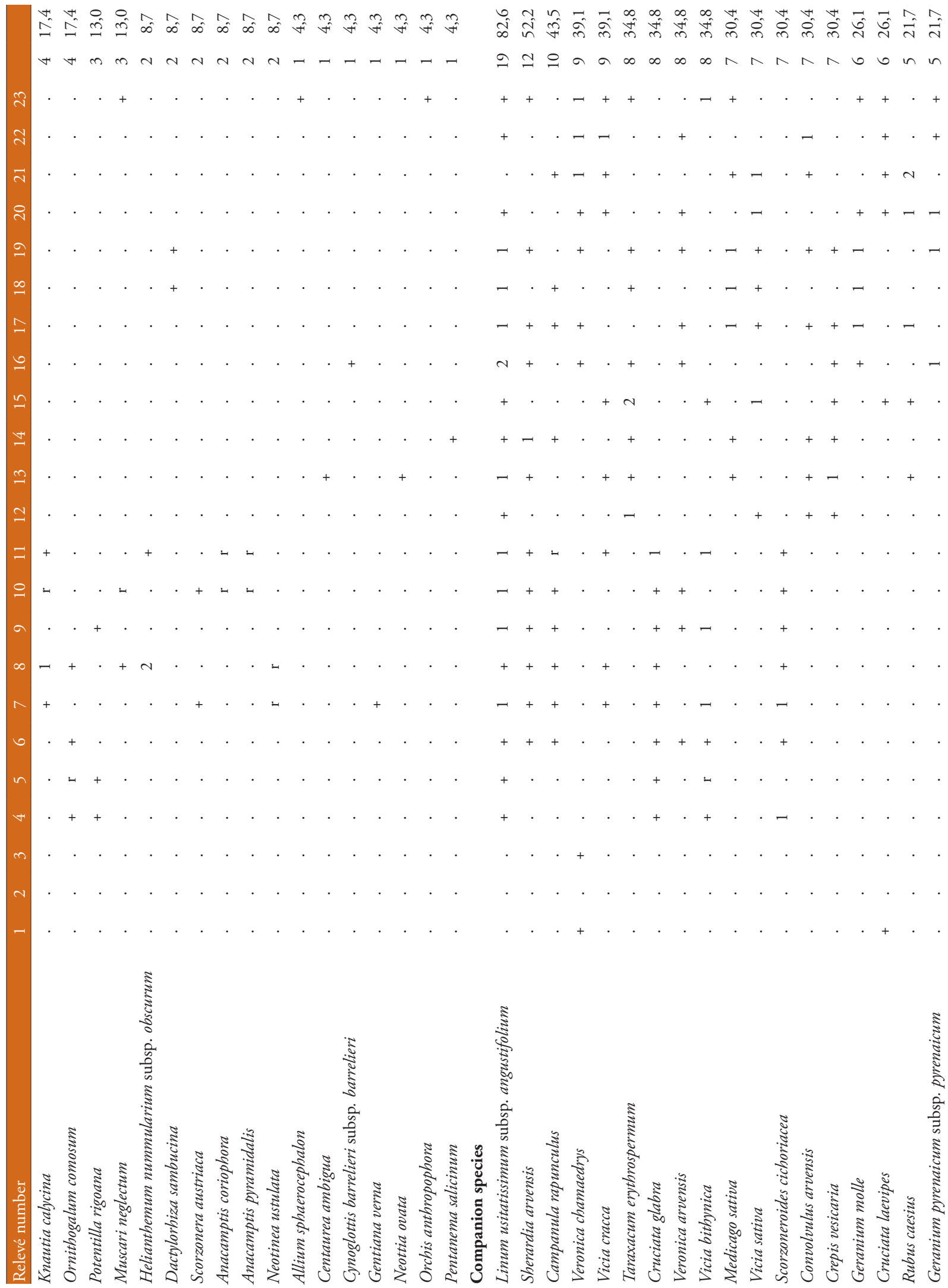




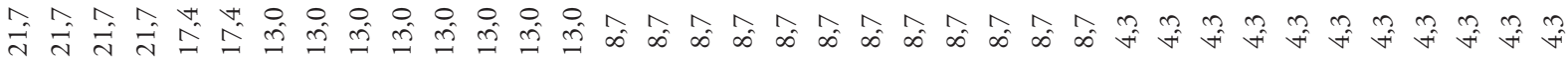

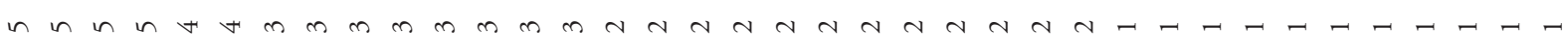

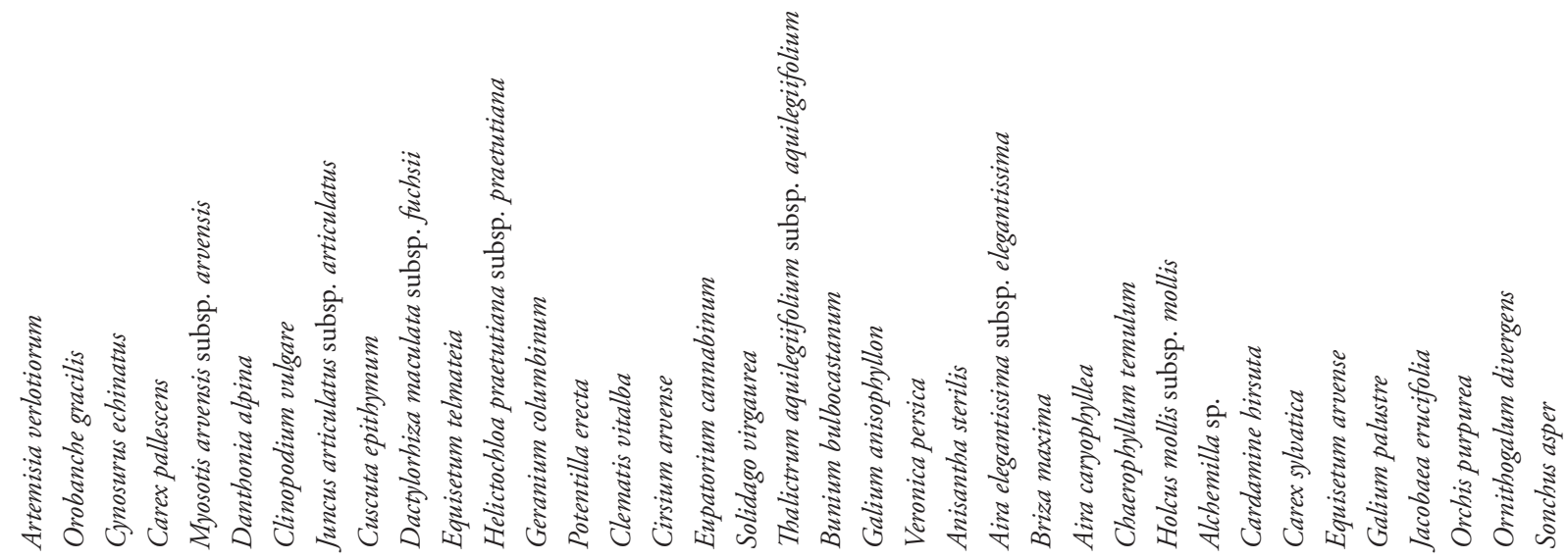




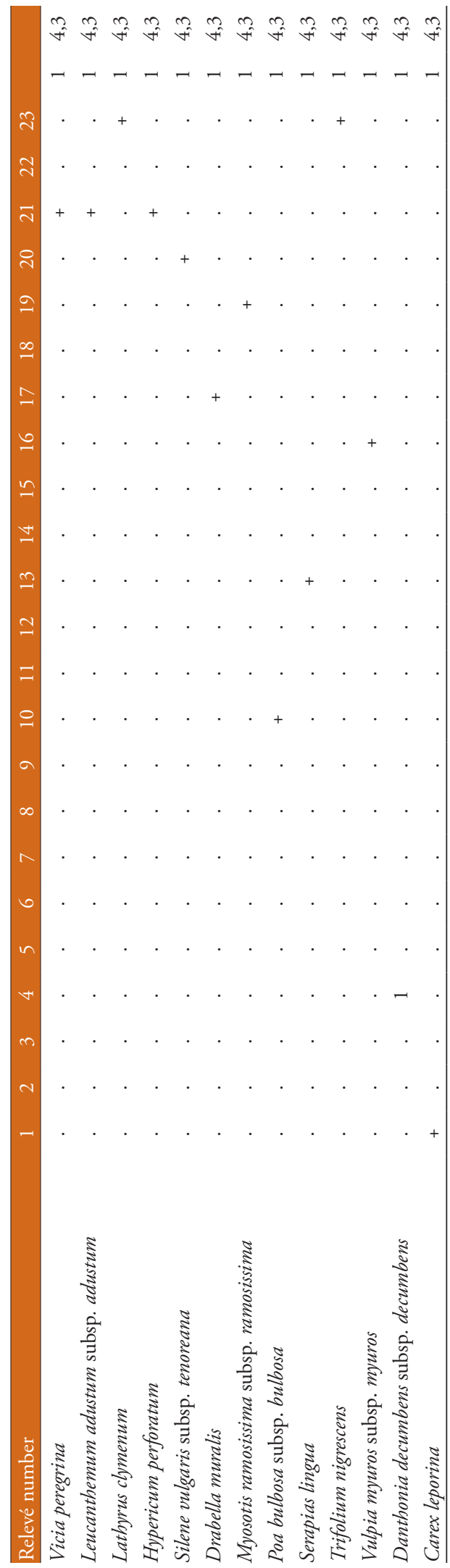

